\title{
WestVirginiaUniversity
}

THE RESEARCH REPOSITORY @ WVU

Graduate Theses, Dissertations, and Problem Reports

1999

\section{Size fractionation of bacterial functional diversity within soils}

Krista Lynne Kinneer

West Virginia University

Follow this and additional works at: https://researchrepository.wvu.edu/etd

\section{Recommended Citation}

Kinneer, Krista Lynne, "Size fractionation of bacterial functional diversity within soils" (1999). Graduate Theses, Dissertations, and Problem Reports. 1023.

https://researchrepository.wvu.edu/etd/1023

This Thesis is protected by copyright and/or related rights. It has been brought to you by the The Research Repository @ WVU with permission from the rights-holder(s). You are free to use this Thesis in any way that is permitted by the copyright and related rights legislation that applies to your use. For other uses you must obtain permission from the rights-holder(s) directly, unless additional rights are indicated by a Creative Commons license in the record and/ or on the work itself. This Thesis has been accepted for inclusion in WVU Graduate Theses, Dissertations, and Problem Reports collection by an authorized administrator of The Research Repository @ WVU. For more information, please contact researchrepository@mail.wvu.edu. 


\title{
SIZE FRACTIONATION OF BACTERIAL FUNCTIONAL DIVERSITY WITHIN SOILS
}

\author{
Krista L. Kinneer
}

\section{THESIS}

Submitted to the College of Agriculture, Forestry, and Consumer Sciences of West Virginia University in partial fulfillment of the requirements

for the Degree of

Master of Science

in

Plant and Soil Sciences

with a concentration in Environmental Microbiology

\author{
Alan Sexstone, Ph.D., Chair \\ Daniel Panaccione, Ph.D. \\ Gary Bissonnette, $\mathrm{Ph} . \mathrm{D}$. \\ Louis McDonald, Ph.D. \\ Department of Plant Pathology and Environmental Microbiology
}

Morgantown, West Virginia

1999

Keywords: Functional diversity, BIOLOG ${ }^{\circledR}$, dilution enrichment, 16SrDNA 


\begin{abstract}
Size fractionation of bacterial functional diversity within soils Krista L. Kinneer

BIOLOG $^{\circledR}$ GN and GP microtitre plates were used to compare functional diversity of large $(>0.45 \mu \mathrm{m}, \mathrm{LC})$ and small $(<0.45 \mu \mathrm{m}, \mathrm{SC})$ cells within A and B horizons of cultivated and forested Guernsey silt-loam soil without enrichment and following enrichment in dilution culture. Without enrichment, SC exhibited limited substrate utilization compared with LC. B horizon SC failed to positively utilize any carbon substrates, which suggests that they may be physiologically inactive and/or metabolically distinct from those in A horizon soils. Following enrichment, A horizon SC from highly diluted enrichment cultures produced substrate utilization patterns distinct both from all enrichments of LC and from SC obtained in less dilute enrichments. At any given inoculum dilution, A horizon SC exhibited greater substrate utilization than B horizon SC, which exhibited positive substrate utilization following enrichment. Amplified ribosomal DNA (ARDRA) analyses of SC dilution culture enrichments demonstrated distinct bacterial sub-populations from a single soil sample.
\end{abstract}




\section{DEDICATION}

This work is dedicated to my parents, Neil and Donna Kinneer. Thank you for supporting me throughout my academic career and for teaching me the value of hard work! 


\section{ACKNOWLEDGEMENTS}

I wish to extend a sincere thank-you to my major advisor, Dr. Alan J. Sexstone, for his guidance throughout my graduate career. Dr. Sexstone, thank you for your encouragement and friendship_-you have made my graduate experience a wonderful one!

I gratefully acknowledge my graduate committee, including Drs. Gary Bissonnette, Daniel Panaccione, and Louis McDonald for invaluable suggestions, assistance, and constructive criticism. Special thanks to Dr. Daniel Panaccione for his patient and thorough instruction during all phases of this research involving molecular techniques. I wish to thank Dr. John Sencindiver for confirming soil type at both study sites, and Dr. Joseph Morton for help with scanning and PhotoShop software programs. I am indebted to Dr. Sara Wright, USDA/ARS Beltsville, MD, for use of her microplate reader for $\mathrm{BIOLOG}^{\circledR}$ data collection.

Kelly Heldreth-Fleming deserves special recognition for her tremendous and invaluable help throughout this research project, including data entry, assistance in developing the cell extraction/size-fractionation procedure, and constant support and encouragement from the moment I arrived at WVU. Thank you so much! I also wish to thank Jim Fleming for cheerfully volunteering to help with soil sampling. I also wish to thank every graduate student in the Department of Plant Pathology and Environmental Microbiology with whom I've had the pleasure of working. I have learned more from all of you than I could in any classroom. Special thanks are extended to my family and to Daniel DeFede. Without your love, support, and patience, I could not have completed my degree. 


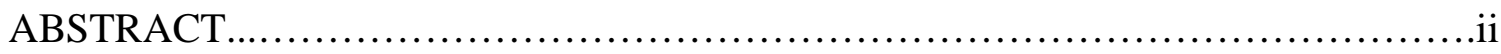

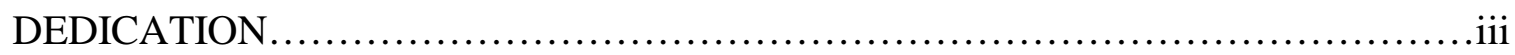

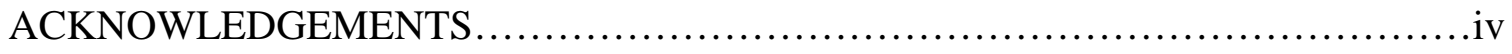

TABLE OF CONTENTS ..........................................................

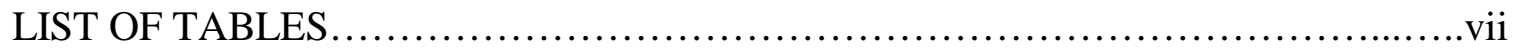

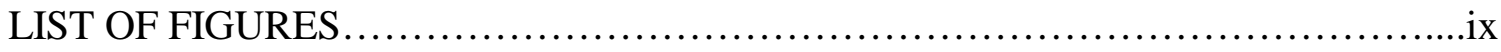

GENERAL INTRODUCTION .................................................

CHAPTER 1. DIFFERENTIAL RESPONSE OF SIZE-FRACTIONATED SOIL BACTERIA IN BIOLOG ${ }^{\circledR}$ MICROTITRE PLATES ..........................9

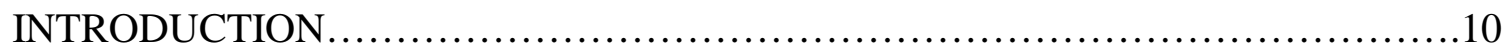

MATERIALS AND METHODS ..................................................11

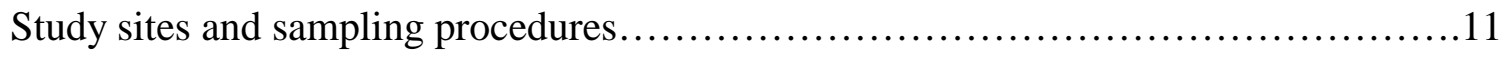

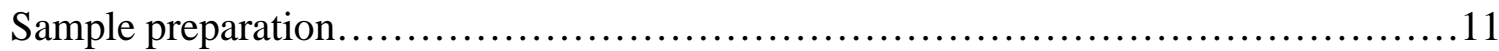

Inoculation and reading of $\mathrm{BIOLOG}^{\circledR}$ plates..........................................12

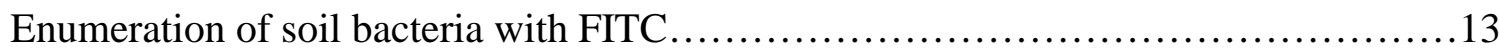

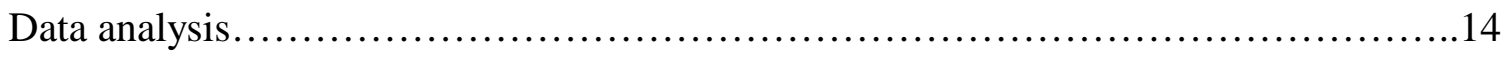

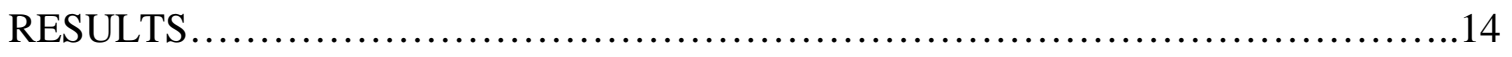

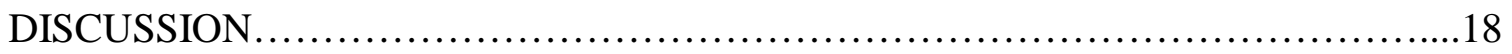

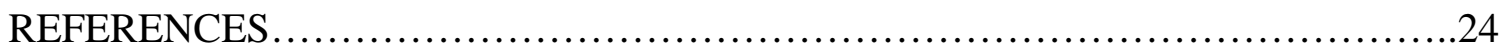

CHAPTER 2. CHARACTERIZATION OF DILUTION ENRICHMENT

CULTURES OBTAINED FROM SIZE-FRACTIONATED SOIL

BACTERIA BY BIOLOG ${ }^{\circledR}$ SUBSTRATE UTILIZATION

PATTERNS AND RESTRICTION ANALYSIS OF 16S rRNA GENES.

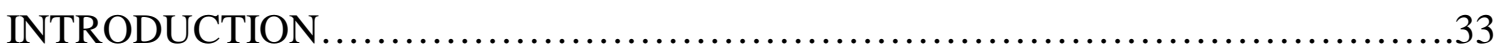




\section{TABLE OF CONTENTS (continued)}

Page

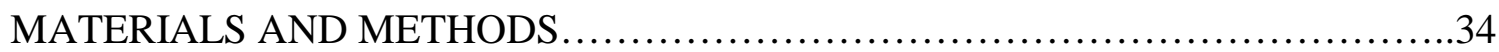

Study sites and sampling procedures.......................................... 34

Sample preparation.................................................... 34

Inoculation of dilution cultures.................................................

BIOLOG $^{\circledR}$ inoculation.......................................................

Cell measurement.............................................................

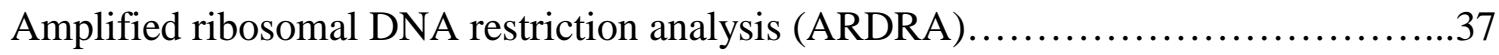

Data analysis............................................................

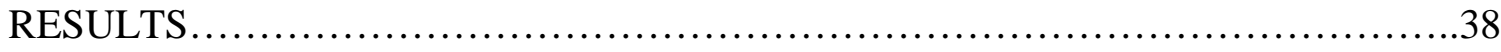

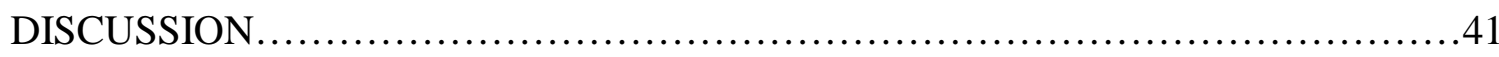

REFERENCES .......................................................47

APPENDIX I. METHODS OF CELL EXTRACTION,

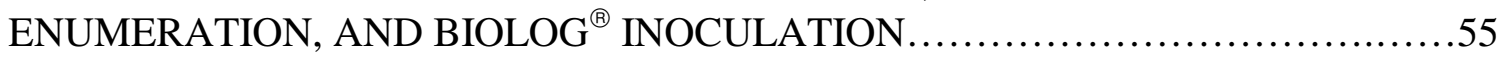

APPENDIX II. ADDITIONAL DATA NOT PRESENTED IN CHAPTER 2 .........57 
Table

\section{LIST OF TABLES}

\section{CHAPTER 1}

1. Bacterial numbers in forested and cultivated Guernsey silt loam soil determined by direct microscopic counts

2. Bacterial functional diversity indices determined in forested and cultivated Guernsey silt loam soil as determined with GN and GP $\mathrm{BIOLOG}^{\circledR}$ microtitre plates

3. Average richness (absorbance $>0.25$ ) within substrate guilds of GN and GP BIOLOG ${ }^{\circledR}$ microtitre plates inoculated with size-fractionated bacteria from forested and cultivated Guernsey silt loam soil....

\section{CHAPTER 2}

1. Functional diversity indices determined in A horizon forested and cultivated Guernsey silt loam soil using GN BIOLOG ${ }^{\circledR}$ plates inoculated with large and small cells enriched in dilution culture....

2. Functional diversity indices determined in A and B horizon forested and cultivated Guernsey silt loam soil using GN BIOLOG ${ }^{\circledR}$ plates inoculated with small cells enriched in dilution culture.

\section{APPENDIX II}

1. Estimated width and length of small cells extracted from A and B horizons of forested and cultivated Guernsey silt-loam soil following enrichment in dilution culture

2. Estimated width and length of small (SC) and large (LC) cells extracted from A and B horizons of forested and cultivated Guernsey silt-loam soil without enrichment.

3. Average richness per substrate guild determined in GN BIOLOG ${ }^{\circledR}$ plates inoculated with small-celled bacteria $(<0.45 \mu \mathrm{m})$ extracted from A and B horizons of forested and cultivated Guernsey silt-loam soil and enriched in dilution culture.

4. Specific substrates utilized by selected enrichment cultures of small-celled bacteria extracted from forested A horizon Guernsey silt-loam soil 


\section{LIST OF TABLES (continued)}

Table

Page

5. Specific substrates utilized by selected enrichment cultures of small-celled bacteria extracted from cultivated A horizon Guernsey

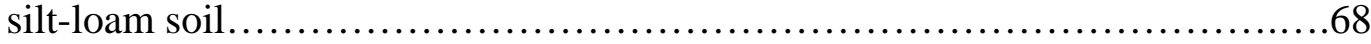


Figure

\section{LIST OF FIGURES}

\section{CHAPTER 1}

1. Average well color development (AWCD) from GN and

GP BIOLOG ${ }^{\circledR}$ plates with time for large (LC) and small (SC) cell size-fractionated bacteria extracted from forested and cultivated Guernsey silt-loam soil

2. Principle component analyses based on adjusted AWCD (average absorbance value for each substrate divided by AWCD) from GN and GP BIOLOG ${ }^{\circledR}$ plates.

\section{CHAPTER 2}

1. Principle component analyses of large and small cells extracted from A horizons of forested and cultivated Guernsey silt-loam soil and enriched in dilution culture.

2. Principle component analyses of small cells extracted from A and B horizons of forested and cultivated Guernsey silt-loam soil and enriched in dilution culture...

3. ARDRA analyses of small-celled bacteria extracted from A and B horizons of forested and cultivated Guernsey silt-loam soil and enriched in dilution culture.

4. Relationships among small cells from A and B horizons of cultivated and forested Guernsey silt-loam soil established using the UPGMA (Unweighted Pair Group Maximum Averages) method, based on a distance matrix generated from RFLPs in 16S rDNA (combined Sau $3 \mathrm{AI}$ and Rsa I data)....

\section{APPENDIX I}

1. Methods of cell extraction, enumeration, and BIOLOG ${ }^{\circledR}$ inoculation.

\section{APPENDIX II}

1. Average well color development (AWCD) from GN BIOLOG ${ }^{\circledR}$

plates with time for large (LC) and small (SC)-celled bacteria extracted from A horizon forested Guernsey silt-loam soil and enriched in dilution culture. 


\section{Figure}

\section{LIST OF FIGURES (continued)}

2. Average well color development (AWCD) from GN BIOLOG ${ }^{\circledR}$ plates with time for large (LC) and small (SC)-celled bacteria extracted from A horizon cultivated Guernsey silt-loam soil and enriched in dilution culture...

3. Average well color development (AWCD) from GN BIOLOG ${ }^{\circledR}$ plates with time for small-celled bacteria extracted from A horizon cultivated and forested Guernsey silt-loam soil and enriched in dilution culture.

4. Principle component analysis based on adjusted AWCD (average absorbance value for each substrate divided by AWCD) from GN BIOLOG $^{\circledR}$ plates inoculated with small-celled bacteria extracted from A and B horizons of forested and cultivated Guernsey silt-loam soil

5. Average well color development (AWCD) per substrate guild from GN BIOLOG $^{\circledR}$ plates inoculated with small-celled (SC) bacteria extracted from A and B horizons of forested Guernsey silt-loam soil and enriched in dilution culture.

6. Average well color development (AWCD) per substrate guild from GN BIOLOG $^{\circledR}$ plates inoculated with small-celled (SC) bacteria extracted from A and B horizons of cultivated Guernsey silt-loam soil and enriched in dilution culture 


\section{GENERAL INTRODUCTION}

Historically, biodiversity has been described in terms of macro-organisms with little consideration of microorganisms (Pace, 1997). Lack of confidence among microbiologists in culture/isolation methodology, large variability and diversity among bacterial populations, and difficulty in applying classic taxonomical methodology are among the reasons microorganisms have been largely overlooked (Bakken, 1997). Regardless of these limitations, understanding microbial biodiversity is important if we are to expand our knowledge about the strategies and limits of life (Zlatkin et al., 1996), the importance of microbes to sustainability of life (Kennedy and Smith, 1995), and understanding our own evolutionary history. Commercially, exploring microbial diversity may reveal novel genes and organisms of value to biotechnology (Istock et al., 1996; Rheims et al., 1996) and may enable us to use diversity patterns to monitor and predict environmental change (Borneman and Triplett, 1997; Smit et al., 1997).

One gram of soil can contain more than $10^{10}$ bacterial cells (Torsvik et al., 1996), of which less than 1\% can be isolated and grown in culture (Torsvik et al., 1990). Therefore, isolated bacteria may account for only a minor fraction of the total bacterial diversity in soil, while our knowledge of the dominant part is very scant.

The majority of soil bacteria are "dwarves", having cell diameters less than $0.3 \mu \mathrm{m}$. These numerically abundant cells represent the major part of the nonculturable bacteria in soil (Bakken and Olsen, 1986). These small cells may represent a distinct population (Bakken and Olsen, 1986) or could be derived from larger cells that shrink as a response to starvation (Novitsky and Morita, 1976). Bottomley and Dughri (1989) noticed that the fraction of small cells within the soil bacterial community increased with soil depth, indicating a relationship between nutrient availability and the presence of dwarves. Their data support the hypothesis that 
small "dwarf" cells are miniatures of otherwise larger "normal-sized" bacteria that shrink in response to starvation. However, of the few dwarf cells able to form colonies on low-nutrient agar, the majority (80-90\%) retains a small cell size during growth (Bakken and Olsen, 1986). Lindahl et al. (1997) demonstrated that small cells $(<0.40 \mu \mathrm{m})$ contained sufficient phospholipids to support intact cell membranes. Dwarf cell DNA-content $\left(1.6-2.4 \mathrm{fg}\right.$ cell $\left.{ }^{-1}\right)$ is similar to that of larger cells (Bakken and Olsen, 1989), suggesting that a majority of these cells contain intact genomes. These data provide evidence for the hypothesis that dwarf cells may indeed be a distinct community separate from larger-celled bacteria.

The development of molecular techniques for directly characterizing microbial communities without cultivation has greatly increased our knowledge of bacterial community structure (Stahl, 1997; Fuhrman, 1997; Pepper, 1997). Since the mid-1980s, the use of 16S ribosomal ribonucleic acid (rRNA) based techniques has facilitated the identification of a wide variety of as yet uncultivated microorganisms from various environments (Torsvik et al., 1990; Ward et al., 1990; Weller et al., 1991). However, most molecular methods still require culturebased information for interpretation of results and assembling a more complete picture of the organisms' ecological properties (Liesack et al., 1997; Chandler et al., 1997). Molecular studies can indicate the presence of microorganisms but often fail to tell us what the role of these in the habitat might be.

Garland and Mills (1991) proposed that sole-carbon source utilization could be used as a functionally based measure for classifying diversity of microbial communities. Characterization is based on patterns of substrate utilization exhibited on BIOLOG ${ }^{\circledR}$ Gram-negative (GN) and Gram-positive (GP) microtiter plates (Biolog Inc., Hayward, CA), each containing 95 solecarbon substrates and a redox indicator, tetrazolium dye (Garland, 1996a; Garland, 1996b; 
Bossio and Scow, 1995; Lindstrom et al., 1998). By combining GN and GP microplates in an analysis, a large number (128) of distinct carbon compounds can be used to evaluate the functional diversity of microbial communities. While these plates were originally designed to identify pure cultures of single isolates based on their pattern of substrate use, community-level information can be obtained by inoculating the plates with whole environmental samples.

Substrate use patterns are then quantified by comparing tetrazolium dye color development in each of the test wells to a control well containing no carbon substrate. Although the exact population densities and taxonomic composition of the communities may not be known, patterns of functional diversity exhibited by $\mathrm{BIOLOG}^{\circledR}$ plates can provide some insight into the activity of microbial communities.

The BIOLOG ${ }^{\circledR}$ method requires that microorganisms be metabolically active under given laboratory conditions, which differ from the natural environmental conditions. It can only detect aerobic respiratory activity—metabolic potential and growth. Therefore, substrate utilization patterns cannot be expected to reflect the metabolic activity of the entire soil community. However, the $\mathrm{BIOLOG}^{\circledR}$ system is useful in that it may reveal the activity of many culturable and metabolically-active but non-culturable cells. Garland (1997) correlated overall color development to total counts estimated by acridine orange staining, plate counts using R2A agar, and active cell counts estimated by reduction of the fluorescent redox dye, 5-cyano-2,3-ditolyl tetrazolium chloride (CTC). Results indicated that active cell counts obtained from CTC analyses were better predictors of the overall rate of color development, suggesting that active organisms that are not culturable on solid media can respond in the BIOLOG ${ }^{\circledR}$ wells. Therefore, it is possible that the $\mathrm{BIOLOG}^{\circledR}$ system may detect the activity of the largely unculturable dwarf cell community. 
With few exceptions, speculations on the role of an organism in its habitat are very difficult without laboratory culture studies. Thus, even with alternative methods available for the detection and characterization of microbial communities, the need to isolate representative strains of microorganisms remains. Recently, dilution culture techniques have been successfully employed to obtain small-celled bacterial isolates in culture (Button et al., 1993; Schut et al., 1993; Janssen et al., 1997). A low-nutrient liquid medium supports the growth of oligotrophic bacteria, while the dilution itself separates different bacterial populations by decreasing competitive exclusion. Janssen et al. (1997) obtained a novel, anaerobic ultramicrobacterium (cell volume $<0.04 \mu^{3}$ ) through this method, and observed that large bacteria dominated the less-dilute tubes, smaller bacteria dominated the most dilute tubes, and very small cells dominated the tubes in the middle. Use of the dilution culture technique allows for the growth of different bacterial populations from a single soil sample (Jackson et al., 1998). Dilution cultures select for organisms present in high numbers in the sample, if they can grow in the media used. Dilution cultures have advantages for studying oligotrophic bacteria because culture selection favors the most abundant, rather than the most nutrient-tolerant, organisms (Button et al., 1993). Since dwarf cells are the most abundant bacteria in soil, dilution cultures may provide an approach to isolating these numerically significant bacteria.

The overall objective of this research was to assess functional diversity to compare sizefractionated bacterial populations within and among sites of a single soil taxon. Specific objectives included: (1) investigating differences in $\mathrm{BIOLOG}^{\circledR}$ patterns among small cells $(<0.45 \mu \mathrm{m})$ and large cells $(>0.45 \mu \mathrm{m})$ by comparing A and B horizon soils at cultivated and forested sites (Chapter One); and, (2) performing a dilution culture enrichment in an attempt to isolate and cultivate small cells within and among the study sites. The BIOLOG ${ }^{\circledR}$ system and 
restriction analysis of PCR-amplified $16 \mathrm{~S}$ rDNA were employed to evaluate the outcome of this enrichment attempt (Chapter Two). 


\section{References}

Bakken, L.R., 1997. Culturable and nonculturable bacteria in soil. In: van Elsas, J.D., Trevors, J.T., Wellington, E.M.H. (Eds.), Modern Soil Microbiology. Marcel Dekker, Inc., New York.

Bakken, L.R., Olsen, R.A., 1986. Dwarf cells in soil—a result of starvation of "normal" bacteria, or a separate population? In: Megusar, F., Gantar, M. (Eds.), Perspectives in Microbial Ecology: Proceedings of the $4^{\text {th }}$ International Symposium on Microbial Ecology. Slovene Society for Microbiology, Jamnikarjeva.

Bakken, L.R., Olsen, R.A., 1989. DNA-content of soil bacteria of different cell size. Soil Biology and Biochemistry 21, 789-793.

Borneman, J., Triplett, E.W., 1997. Molecular microbial diversity in soils from eastern Amazonia: evidence for unusual microorganisms and microbial population shifts associated with deforestation. Applied and Environmental Microbiology 63, 2647-2653.

Bossio, D.A., Scow, K.M., 1995. Impact of carbon and flooding on the metabolic diversity of microbial communities in soils. Applied and Environmental Microbiology 61, 40434050 .

Bottomley, P., Dughri, M.H., 1989. Population size and distribution of Rhizobium leguminosarum bv. trifolii in relation to total soil bacteria and soil depth. Applied and Environmental Microbiology 55, 959-964.

Button, D.K., Schut, F., Quang, P., Martin, R., Robertson, B.R., 1993. Viability and isolation of marine bacteria by dilution culture: theory, procedures, and initial results. Applied and Environmental Microbiology 59, 881-891.

Chandler, D.P., Li, S.M., Spadoni, C.M., Drake, G.R., Balkwill, D.L., Frederickson, J.K., Brockman, F.J., 1997. A molecular comparison of culturable aerobic heterotrophic bacteria and 16S rDNA clones derived from a deep subsurface sediment. FEMS Microbiology Ecology 23, 131-144.

Fuhrman, J.A., 1997. Community structure: bacteria and archaea. In: Hurst, C.J., Knudsen, G.R., McInerney, M.J., Stetzenbach, L.D., Walter, M.V. (Eds.), Manual of Environmental Microbiology. ASM Press, Washington D.C.

Garland, J.L, Mills, A.L., 1991. Classification and characterization of heterotrophic microbial communities on the basis of patterns of community-level sole-carbon source utilization. Applied and Environmental Microbiology 57, 2351-2359. 
Garland, J.L., 1996a. Analytical approaches to the characterization of samples of microbial communities using patterns of potential carbon source utilization. Soil Biology and Biochemistry 28, 213-221.

Garland, J.L., 1996b. Patterns of potential carbon source utilization by rhizosphere communities. Soil Biology and Biochemistry 28, 223-230.

Garland, J.L., 1997. Analysis and interpretation of community-level physiological profiles in microbial ecology. FEMS Microbiology Ecology 24, 289-300.

Istock, C.A., Bell, J.A., Ferguson, N., Istock, N.L., 1996. Bacterial species and evolution: theoretical and practical perspectives. Journal of Industrial Microbiology 17, 137-150.

Jackson, C.R., Roden, E.E., Churchill, P.F., 1998. Changes in bacterial species composition in enrichment cultures with various dilutions of inoculum as monitored by denaturing gradient gel electrophoresis. Applied and Environmental Microbiology 64, 5046-5048.

Janssen, P.H., Schuhmann, A., Morschel, E., Rainey, F.A., 1997. Novel anaerobic ultramicrobacteria belonging to the Verrucomicrobiales lineage of bacterial descent isolated by dilution culture from anoxic rice paddy soil. Applied and Environmental Microbiology 63, 1382-1388.

Kennedy, A.C., Smith, K.L., 1995. Soil microbial diversity and the sustainability of agricultural soils. Plant and Soil 170, 75-86.

Liesack, W., Janssen, P.H., Rainey, F.A., Ward-Rainey, N.L., Stackebrandt, E., 1997. Microbial diversity in soil: the need for a combined approach using molecular and cultivation techniques. In: van Elsas, J.D., Trevors, J.T., Wellington, E.M.H. (Eds.), Modern Soil Microbiology. Marcel Dekker, Inc., New York.

Lindahl, V., Frostegard, A., Bakken, L., Baath, E., 1997. Phospholipid fatty acid composition of size fractionated indigenous soil bacteria. Soil Biology and Biochemistry 29, 1565-1569.

Lindstrom, J.E., Barry, R.P., Braddock, J.F., 1998. Microbial community analysis: a kinetic approach to constructing potential C source utilization patterns. Soil Biology and Biochemistry 30, 231-239.

Novitsky, J.A., Morita, R.Y., 1976. Morphological characterization of small cells resulting from nutrient starvation of a psychrophilic marine Vibrio. Applied and Environmental Microbiology 32, 617-622.

Pace, N.R., 1997. A molecular view of microbial diversity and the biosphere. Science 276, 734740. 
Pepper, I.L., 1997. PCR: applications for plant and soil microbes. In: Hurst, C.J., Knudsen, G.R., McInerney, M.J., Stetzenbach, L.D., Walter, M.V. (Eds.), Manual of Environmental Microbiology. ASM Press, Washington D.C.

Rheims, H., Rainey, F.A., Stackebrandt, E., 1996. A molecular approach to search for diversity among bacteria in the environment. Journal of Industrial Microbiology 17, 159-169.

Schut, F., De Vries, E.J., Gottschal, J.C., Robertson, B.R., Harder, W., Prins, R.A., Button, D.K., 1993. Isolation of typical marine bacteria by dilution culture: growth, maintenance, and characteristics of isolates under laboratory conditions. Applied and Environmental Microbiology 59, 2150-2160.

Smit, E., Leeflang, P., Wernars, K., 1997. Detection of shifts of microbial community structure and diversity in soil caused by copper contamination using amplified ribosomal DNA restriction analysis. FEMS Microbiology Ecology 23, 249-261.

Stahl, D.A., 1997. Molecular approaches for the measurement of density, diversity, and phylogeny. In: Hurst, C.J., Knudsen, G.R., McInerney, M.J., Stetzenbach, L.D., Walter, M.V. (Eds.), Manual of Environmental Microbiology. ASM Press, Washington D.C.

Torsvik, V., Goksoyr, J., Daae, F.L., 1990. High diversity in DNA of soil bacteria. Applied and Environmental Microbiology 56, 782-787.

Torsvik, V., Sorheim, R., Goksoyr, J., 1996. Total bacterial diversity in soil and sediment communities - a review. Journal of Industrial Microbiology 17, 170-178.

Ward, D.M., Weller, R., Bateson, M.M., 1990. 16S rRNA sequences reveal numerous uncultured microorganisms in a natural community. Nature 345, 63-65.

Weller, R., Weller, J.W., Ward, D.M., 1991. 16S rRNA sequences of uncultivated hot spring cyanobacterial mat inhabitants retrieved as randomly primed cDNA. Applied and Environmental Microbiology 57, 1146-1151.

Zlatkin, I.V., Schneider, M., de Bruijn, F.J., Forney, L.J., 1996. Diversity among bacteria isolated from the deep subsurface. Journal of Industrial Microbiology 17, 219-227. 


\section{CHAPTER 1}

Differential response of size-fractionated soil bacteria in BIOLOG ${ }^{\circledR}$ microtitre plates 


\section{Introduction}

Bacterial cells less than $0.4 \mu \mathrm{m}$ in diameter are numerically abundant in soil, but due to unknown growth requirements rarely are recovered on standard microbiological media (Bakken and Olsen, 1986). Some examples obtained in culture retain their small size during growth and possess a DNA-content cell ${ }^{-1}$ of 1.5-2.1 fg (Bakken and Olsen, 1989). These small bacteria contain sufficient phospholipid fatty acid content to support intact cell membranes and are predominantly Gram-positive (Lindahl et al., 1997). Populations of small soil bacteria deserve attention, since they may represent species not yet studied in culture whose metabolic activities are still largely unknown.

Direct inoculation of environmental samples into BIOLOG $^{\circledR}$ microtitre plates (Biolog

Inc., Hayward, CA) containing 95 different sole-carbon substrates produces patterns of potential C source utilization for microbial communities. This method previously has been used to characterize microbial communities within and among different soil types (Garland and Mills, 1991; Winding, 1994; Zak et al., 1994; Bossio and Scow, 1995; Haack et al., 1995; Staddon et al., 1997;) rhizosphere samples (Garland and Mills, 1994; Garland, 1996a; Garland, 1996b), model communities (Haack et al., 1995), and groundwater samples (Fliermans et al., 1997). The community characterizations obtained are inherently selective since they depend on bacterial growth and/or respiration on the various BIOLOG ${ }^{\circledR}$ substrates. It is unclear whether small bacterial cells significantly contribute to the substrate utilization pattern observed when BIOLOG $^{\circledR}$ plates are inoculated with a mixed microbial community from soil. Garland (1997) suggested that metabolically active bacteria that are not culturable on solid media might respond in the BIOLOG ${ }^{\circledR}$ wells. Thus, the $\mathrm{BIOLOG}^{\circledR}$ method may reveal the metabolic potential of selected small soil bacteria and assist in the enrichment of isolates. 
The purpose of this study was to determine if BIOLOG $^{\circledR}$ patterns differed between small cells $(<0.45 \mu \mathrm{m})$ and large cells $(>0.45 \mu \mathrm{m})$ obtained from a single soil taxon. Differences in the bacterial community from A and B horizons from a cultivated and forested site were evaluated. Our working hypothesis was that BIOLOG ${ }^{\circledR}$ patterns would differ between the small and large cell fraction, demonstrating that small cells are metabolically distinct from larger cells.

\section{Materials and Methods}

\section{Study sites and sampling procedures}

Two sites were studied: a cultivated site, which has undergone regular tillage since 1976; and, a forested site, a naturally wooded area dominated by deciduous trees. The soil type at both sites is a Guernsey silt loam (fine, mixed, mesic Aquic Hapludalfs). The sites are immediately adjacent to each other on the West Virginia University Plant Sciences Farm in Morgantown, WV $\left(39.63^{0} \mathrm{~N}, 79.95^{0} \mathrm{~W}\right)$.

Multiple core samples were taken from each site with a split-core soil sampler. Samples from the A and B horizon were separated on site and placed into separate plastic bags for immediate transport to the laboratory, where they were individually bulked and coarse-sieved (4.75 mm mesh size). All samples were stored at field moisture in sealed plastic bags and were refrigerated at $4 \mathrm{C}$ until use.

\section{Sample preparation}

For each of the four soil samples, $50 \mathrm{~g}$ soil, $200 \mathrm{ml}$ Winogradsky's salt solution $(5.0 \mathrm{~g}$ $\mathrm{K}_{2} \mathrm{HPO}_{4}, 5.0 \mathrm{~g} \mathrm{MgSO}_{4} \cdot 7 \mathrm{H}_{2} \mathrm{O}, 2.5 \mathrm{~g} \mathrm{NaCl}, 0.05 \mathrm{~g} \mathrm{Fe}_{2}\left(\mathrm{SO}_{4}\right)_{3} \cdot \mathrm{H}_{2} \mathrm{O}, 0.05 \mathrm{~g} \mathrm{Mn}_{2}\left(\mathrm{SO}_{4}\right)_{3} \cdot 4 \mathrm{H}_{2} \mathrm{O}$,

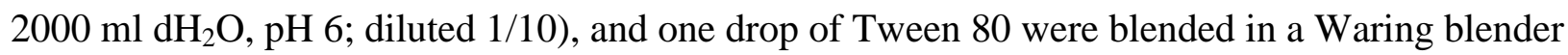
for three 1-min intervals with intermittent cooling in an ice bath. This was repeated until six 250 
ml centrifuge bottles (Nalgene ${ }^{\circledR}$, polyethylene) per horizon and study site were filled with soil homogenate. Large soil particles were removed by centrifugation at $2500 \mathrm{rev} \mathrm{min}^{-1}$ for $15 \mathrm{~min}$ at $4 \mathrm{C}$ in a Sorvall ${ }^{\circledR}$ RC-5B Refrigerated Superspeed Centrifuge and a Sorvall ${ }^{\circledR}$ GSA rotor. The resulting supernatants from each site and soil horizon were pooled and added to $500 \mathrm{ml}$ Winogradsky's salt solution.

To separate bacterial cells according to size, each cell solution was passed through 0.45 $\mu \mathrm{m}$ Millipore HA filters. The filtrate contained bacterial cells smaller than $0.45 \mu \mathrm{m}$ in diameter and represented the small cell (SC) fraction. Large cells (LC) greater than $0.45 \mu \mathrm{m}$ in diameter were collected by washing material from the surface of the filters, by placing them into Petri plates containing Winogradsky's salt solution and shaking on a rotary shaker (Lab-line orbit shaker) at $110 \mathrm{rev} \mathrm{min}^{-1}$ for $15-20 \mathrm{~min}$. A sterile paintbrush (5/32" diameter) was used to brush off any remaining cells from the surface of the filters.

To collect cells, LC and SC samples were centrifuged at 10,000 rev $\mathrm{min}^{-1}, 4 \mathrm{C}$, for 25 min. Supernatants were discarded, and cells were resuspended in $200 \mathrm{ml}$ Winogradsky's salt solution. The cells were then washed three times, to remove soil particles and dissolved carbon, by centrifugation in the same manner.

\section{Inoculation and reading of BIOLOG ${ }^{\circledR}$ plates}

Washed cells were resuspended in $80 \mathrm{ml}$ Winogradsky's salt solution to provide enough inoculum for triplicate GN and GP BIOLOG ${ }^{\circledR}$ microplates (Biolog Inc., Hayward, CA). Before inoculation, the turbidity of all samples was equalized $\left(\mathrm{A}_{595}=0.01\right)$ by dilution based on spectrophotometric (Bausch and Lomb Spectronic 20) readings. Plates were inoculated with 100 $\mu \mathrm{L}$ sample/well to reduce the risk of cross-contamination from well to well during plate reading (Zak et al., 1994). Plates were stored in a plastic container with moist paper towels to maintain 
humidity, and were incubated at $25 \mathrm{C}$. Plates were read on an automated ELISA reader (Dynatech MR4000) equipped with a $595 \mathrm{~nm}$ filter at $12 \mathrm{~h}$ intervals for $120 \mathrm{~h}$. Absorbance values for the wells containing carbon substrate were blanked against the control well. Negative values were considered as 0 in subsequent data analyses.

\section{Enumeration of soil bacteria with FITC}

Soil bacteria were enumerated for samples taken before centrifugation at $2500 \mathrm{rev} \mathrm{min}^{-1}$, after centrifugation at $2500 \mathrm{rev} \mathrm{min}^{-1}$, and from the LC and SC fractions before cell collection and washing. To prepare slides for fluorescence microscopy, $10 \mu \mathrm{L}$ of sample was evenly smeared in a defined area $\left(254 \mathrm{~mm}^{2}\right)$ on a microscope slide, air dried, and heat fixed. Smears were stained with FITC staining solution (1 mg FITC, $0.25 \mathrm{ml} 0.5 \mathrm{M}$ carbonate-bicarbonate buffer $\mathrm{pH} 9.6,1.1 \mathrm{ml} 0.01 \mathrm{M}$ phosphate buffer $\mathrm{pH} 7.2,1.1 \mathrm{ml} \mathrm{0.85 \%} \mathrm{NaCl}$ ) for three min. Slides were washed for $10 \mathrm{~min}$ in $0.5 \mathrm{M}$ carbonate-bicarbonate buffer ( $\mathrm{pH} 9.6$ ), two min in $5 \%$ sodium pyrophosphate, and rinsed in distilled water. Slides were allowed to air dry and were mounted in buffered glycerol (5 ml $1 \mathrm{M} \mathrm{Na}_{2} \mathrm{CO}_{3}$ in $45 \mathrm{ml}$ glycerol, $\mathrm{pH}$ 9.6) for observation with a Nikon Optiphot epifluorescence microscope, equipped with a filter set for blue light (BP 450-490 nm exciter filter, $510 \mathrm{~nm}$ beam splitter, and LP $520 \mathrm{~nm}$ barrier filter). Bacteria numbers were determined by counting the number of bacteria observed in ten random fields of view from each triplicate slide. Bacteria were enumerated according to the following equation:

$$
\mathrm{N}_{\mathrm{g}}=\mathrm{N}_{\mathrm{f}} * \mathrm{~A} * \mathrm{D} * \mathrm{~W}_{\mathrm{w}} / \mathrm{a}_{\mathrm{m}} * \mathrm{v}_{\mathrm{s}} * \mathrm{~W}_{\mathrm{d}},
$$

where $\mathrm{N}_{\mathrm{g}}=$ number of bacteria gram ${ }^{-1}$ (dry weight) soil, $\mathrm{N}_{\mathrm{f}}=$ average number of bacteria per

field of view, $\mathrm{A}=$ area of smear (in this case, $254 \mathrm{~mm}^{2}$ ), $\mathrm{D}=$ dilution factor, $\mathrm{W}_{\mathrm{w}}=$ wet weight of 
soil $(\mathrm{g}), \mathrm{a}_{\mathrm{m}}=$ area of microscope field in $\mathrm{mm}^{2}, \mathrm{v}_{\mathrm{s}}=$ volume spread on slide $(0.01 \mathrm{ml})$, and $\mathrm{W}_{\mathrm{d}}=$ dry weight of soil (g) (Bottomley, 1994).

\section{Data analysis}

All statistical analyses were performed using the JMP statistical software package (SAS Institute, Inc.). Principal component analysis was performed using data normalized by dividing the absorbance value for each substrate by the average well color development (AWCD) for the entire plate (Garland and Mills, 1991; Garland, 1996a). AWCD for plates was calculated as the mean of all blanked absorbance values for all wells containing a carbon substrate. Substrate diversity $(\mathrm{H})$ was calculated as $\mathrm{H}=-\Sigma \mathrm{p}_{\mathrm{i}}\left(\ln \mathrm{p}_{\mathrm{i}}\right)$, where $\mathrm{p}_{\mathrm{i}}$ is the ratio of the absorbance at a particular substrate to the sum of absorbances over the entire plate. Average sum of activities was calculated by averaging the sum of absorbance values from triplicate plates. Substrate richness was determined as the average number of positive wells with an absorbance value greater than 0.25 (Garland, 1997). Substrate richness per guild was determined by averaging the number of positive wells from triplicate plates within each substrate guild.

\section{Results}

Direct bacterial counts determined by fluorescence microscopy ranged from 2.6 to $5.3 \mathrm{x}$ $10^{10}$ cells gram ${ }^{-1}$ dry weight soil (Table 1$)$. Mean counts were slightly higher in forested compared with cultivated soil and decreased with depth at both sites. Utilizing a direct extraction procedure, bacterial cells were separated from the soil matrix and recovered by centrifugation. Approximately 0.8 to $1.8 \%$ of the original direct bacterial counts in soil were

recovered by this procedure (Table 1). Extracted cells from each sample were partitioned into a large $(>0.45 \mu \mathrm{m})$ and small $(<0.45 \mu \mathrm{m})$ size fractions by passage through a membrane filter. 
Appropriate bacterial sizes in each fraction were confirmed by negative staining the filtrates followed by cell measurements $(n>100)$ with an ocular micrometer (data not shown). Approximately twice as many small cells were generally recovered from the soil from both sites and horizons (Table 1).

When $\mathrm{BIOLOG}{ }^{\circledR} \mathrm{GN}$ and GP plates were inoculated with LC bacteria from either the A or B horizon, average well color development (AWCD) values increased rapidly in the interval from 24 to 84 hours (Figure 1). Despite the fact that optical density of the LC and SC inocula were equalized, AWCD increased slower and reached a much lower final average OD when plates were inoculated with the SC fraction. Appreciable increases in AWCD were apparent in A horizon samples but not B horizon samples when SC were used as inocula (Figure 1). GN and GP BIOLOG $^{\circledR}$ control plates inoculated with Winogradsky salt solution alone did not exhibit color development during the $120 \mathrm{~h}$ incubation period.

Functional diversity can be operationally determined from the number and type of BIOLOG $^{\circledR}$ substrates used by a bacterial community (Zak et al., 1994). Typically, BIOLOG ${ }^{\circledR}$ data are compared after a fixed incubation time when absorbance values for most substrates are increasing, but have not approached saturation (Bossio and Scow, 1995; Garland, 1996a). After inspection (Figure 1), data obtained at $60 \mathrm{~h}$ (cultivated site) and $72 \mathrm{~h}$ (forested site) were chosen for further analysis. Total activity and substrate richness for LC decreased with soil depth at both sites (Table 2). Slightly higher values were observed in the cultivated compared with the forested site. Trends were similar for LC regardless of whether GN or GP BIOLOG ${ }^{\circledR}$ plates were employed (Table 2). Little difference in the diversity index (range 4.1 to 4.5) was apparent among samples. In contrast, SC had lower total activity, substrate richness, and diversity (range 3.4 to 3.6) when compared with LC plates (Table 2). In order to eliminate weak positive 
responses in the calculation of substrate richness, an average absorbance value greater than 0.25 was required (Garland, 1997) for substrates to be considered as positively utilized. No substrate was positively utilized by the SC community from the B horizon of either study site, despite the low but measurable total activity recorded (Table 2).

Principle-component analysis (PCA) performed using values for adjusted AWCD distinctly separated the LC fraction (A and B horizon) from the SC fraction (A horizon), regardless of the $\mathrm{BIOLOG}^{\circledR}$ plate utilized (Figure 2). Large cell data grouped similarly with some separation of samples from A and B horizons noted with GP plates. In both cases, SC data were distinctly separated according to site. Among the GP data, PC 1 accounted for $44 \%$ of the observed total variation, while PC 2 and PC 3 accounted for $24 \%$ and $20 \%$, respectively. PC 1 was most positively correlated with glucose-1-phosphate utilization $(r=0.9735)$ and negatively correlated with utilization of D-mannitol ( $\mathrm{r}=-0.9858)$ and L-lactic acid ( $\mathrm{r}=-0.9985)$, while PC 2 correlated with utilization of gentiobiose $(r=-0.9732), \alpha-D$-glucose $(r=0.9903)$, and pyruvic acid $(\mathrm{r}=0.9679)$. With GN plates, PC 1, PC 2, and PC 3, accounted for 49\%, 31\%, and 12\%, of the observed total variation. PC 1 was most positively correlated with utilization of $\beta$ hydroxybutyric acid (r=0.9947) and L-alanyl glycine (0.9944), and most negatively correlated with utilization of D-gluconic acid ( $\mathrm{r}=-0.9958)$ and $\alpha$-keto glutaric acid $(\mathrm{r}=-0.9846)$. PC 2 correlated with $\alpha$-D-glucose $(r=0.9879)$, methyl pyruvate $(r=0.9721)$, and quinic acid utilization $(\mathrm{r}=0.9891)$.

Indices such as AWCD, substrate richness, and substrate diversity provide information about the numbers, activities, and rates at which substrates are utilized, but provide little insight into the types of substrates utilized by bacterial communities. Carbon sources available on GN and GP BIOLOG ${ }^{\circledR}$ plates previously have been divided into six substrate guilds (Zak et al., 
1994). Substrates within each guild differ between GN and GP plates as follows: carbohydrates (30/43/27), carboxylic acids (20/16/12), polymers (5/7/5), amines/amides (6/4/3), amino acids $(20 / 8 / 8)$ and miscellaneous (10/17/8); where numbers in parentheses represent the total number of GN substrates, the total number of GP substrates, and the number of substrates shared on both GN and GP plates, respectively. Based on average substrate richness, LC utilized greater than $75 \%$ of the available substrates in all guilds (Table 3). This trend was apparent regardless of the type of $\mathrm{BIOLOG}^{\circledR}$ plate. In contrast, SC positively utilized less than $25 \%$ of the available carbohydrates, carboxylic acids, and amino acids with no significant utilization of the remaining three substrate guilds (Table 3). Positive substrate use by SC varied within guilds according to site (Table 3).

Data in Tables 2 and 3 represent averages of three replicate BIOLOG $^{\circledR}$ plates. When a substrate was positively utilized by LC (mean OD >0.25) all three replicates generally showed strong color development with relatively little variation among replicates [\% coefficient of variation (CV) less than 30\%]. Much greater variability existed among SC replicates (CV > 80\%). As a result, although an individual replicate might be positive for use of a substrate, examination of the mean of the three replicates would indicate a negative result. These data indicate a greater heterogeneity in the distribution of SC among BIOLOG ${ }^{\circledR}$ wells, perhaps due to dilution to extinction of a relatively small number of cells capable of growth on a particular substrate. If substrate richness is scored according to the presence of a single positive replicate, then the number of total substrates positively utilized by SC increases, reaching values of 28 and 31 for cultivated A horizon GN and GP plates, respectively, and reaching a value of 24 for forested A horizon GN and GP plates. However, the number and type of substrates utilized are still greatly restricted in comparison to LC. 


\section{Discussion}

Comparison of the $\mathrm{BIOLOG}^{\circledR}$ substrate utilization patterns obtained from LC and SC inocula revealed distinct differences in the bacterial community response from A horizon soils of both the forested and cultivated site. In all cases, the number and extent of substrates utilized was much higher for the LC fraction. Small cells used less than $14 \%$ of the available BIOLOG ${ }^{\circledR}$ substrates, primarily from the carbohydrate and carboxylic acid guilds. Distinguishable substrate utilization patterns also were produced by LC from B horizon soils, however SC from the B horizon produced no positive reactions $\left(\mathrm{OD}_{595}>0.25\right)$ on any of the $\mathrm{BIOLOG}^{\circledR} \mathrm{GN}$ or GP substrates employed. The dramatic differences in substrate utilization patterns occurred despite similar numbers of bacteria in the LC and SC inocula.

In microbial diversity studies, preparing an inoculum that is representative of the numbers and types of microorganisms present in the original sample is of primary importance. This has been a problem for soil samples, where the efficiency of releasing cells from the solid matrix is low. Adhesion to soil particles and encasement in soil aggregates are the main reasons for retention of microorganisms in the soil matrix, especially in soils with a high clay or silt content (Riis et al., 1998). Lindahl (1996) extracted <20\% of cells by blending soil slurries in pyrophosphate solution. Combining shaking and ultrasonication, Riis et al. (1998) were able to recover $45 \%$ of the cell counts from soil. In the present study, our cell recovery was much less efficient; i.e., approximately 0.8 to $1.8 \%$ of the original direct bacterial counts were recovered. Inefficient cell recovery has implications on the outcome of microbial functional diversity studies, since it is likely that only the most easily-detachable cells are being recovered. Therefore, the resulting inoculum may not represent the majority of the indigenous soil bacteria that firmly attach to surfaces or are found in aggregates (Lindahl et al., 1996). This has a direct 
effect on the substrate utilization patterns obtained on $\mathrm{BIOLOG}^{\circledR}$ plates, since moribund or physiologically-inactive cells may be among these easily-detachable cells (Riis et al., 1998), and the metabolic potential of many indigenous soil bacteria more firmly attached to soil particles may not be included in the analysis. However, Bakken (1985) has shown, on the basis of cell size distribution, that the fractionation-centrifugation technique releases all bacterial types from soil with equal efficiency through several rounds of homogenation-centrifugation. Holben et al. (1988) suggested that a single round of homogenation-centrifugation results in a soil bacteria fraction representative of the total bacterial population.

The manufacturer recommends that $\mathrm{BIOLOG}^{\circledR}$ plates be inoculated at a density of $10^{8}$ cells $\mathrm{ml}^{-1}$ (Biolog Inc., 1993). However, for most environmental samples the cell density is much lower. Konopka (1998) reported inoculum densities $>10^{5} \mathrm{cells} \mathrm{ml}^{-1}$ are required in order to ensure that the communities inoculated into the individual wells are the same. We estimated that our inoculum contained $10^{5}$ and $10^{6}$ cells $\mathrm{ml}^{-1}$ for the LC and SC, respectively. Therefore, it is likely that the bacterial community was evenly distributed among the $\mathrm{BIOLOG}^{\circledR}$ wells and among replicate plates. Collected cells were extensively washed and inoculum densities equalized prior to inoculation into plates. Lack of color development in control wells indicated there was little carry over of exogenous carbon. There was a similar lag period with both inocula (24 h) prior to significant color development in the BIOLOG $^{\circledR}$ wells, presumably as the inocula multiplied to a sufficient density $\left(10^{8}\right.$ cells $\left.\mathrm{ml}^{-1}\right)$ to produce a positive response (Haack et al., 1995).

Compared with LC we noted much greater variability among SC replicate responses, which might suggest a small number of viable cells that were unequally distributed among the wells. If the density of physiologically active cells in the inoculum is low, it is likely that the 
active community inoculated into the individual wells is not the same, and would therefore result in a variable $\mathrm{BIOLOG}^{\circledR}$ response. Haack et al. (1995) suggested that variability in substrate use among replicates might indicate the presence of rare community members in the inoculum. Such members may exhibit unique substrate utilization on the plates and may be present in such low numbers that they would not be equally distributed among replicate plates.

Although the bacterial size fractions were distinguishable by functional diversity indices, limitations of the methodology preclude our ability to generalize about the populations present. Konopka et al. (1998) suggested that although environmental samples can be differentiated by their substrate utilization patterns, the data obtained may provide incomplete information concerning the authentic microbial diversity or metabolic potential of the communities present. Fundamentally, $\mathrm{BIOLOG}^{\circledR}$ is a culture-based enrichment method that depends on the ability of the community inocula to metabolize or grow; which in turn depends on the environmental relevance of the carbon sources provided and the physiological state of the inoculum. It is a well established problem that less than $1 \%$ of the total direct microscopic count of soil bacteria are culturable on standard laboratory media (Torsvik et al., 1990). It is probable that many of these bacteria do not contribute to $\mathrm{BIOLOG}^{\circledR}$ substrate utilization patterns and thus their contribution to community diversity is overlooked by this method.

Small cells often are numerically abundant in soil and represent a distinct bacterial community that is largely unculturable (Bakken and Olsen, 1989). Garland (1997) suggested that metabolically active bacteria that are not culturable on solid media may respond in the BIOLOG $^{\circledR}$ wells. Thus, the BIOLOG ${ }^{\circledR}$ method may reveal the metabolic potential of small soil bacteria unobtainable in culture. In preliminary work (K. Kinneer, unpublished data) soil bacteria passing a $0.45 \mu \mathrm{m}$ filter occasionally could be cultured on nutrient agar or R2A agar 
(Bacto ${ }^{\circledR}$, Difco laboratories), but cells passing a $0.3 \mu \mathrm{m}$ filter were almost never culturable.

Olsen and Bakken (1987) previously found that less than $1 \%$ of soil bacteria with diameters less than $0.4 \mu \mathrm{m}$ could be grown on complex low-nutrient media. In contrast, up to $38 \%$ of cells in their study larger than $0.4 \mu \mathrm{m}$ were culturable and were unaffected by the carbon content of the media. Substrate utilization patterns exhibited on BIOLOG ${ }^{\circledR}$ plates are reflective of either the original bacterial community, or selective enrichment of fast-growing microbes. In our study, it is likely that the rich and diverse $\mathrm{BIOLOG}^{\circledR}$ patterns obtained with the LC inocula is due to the activity of readily culturable, rapidly growing, copiotrophic bacteria. Unsuitable growth conditions in $\mathrm{BIOLOG}^{\circledR}$ plates for physiologically dormant or oligotrophic autochthonous soil organisms probably resulted in the limited substrate utilization by SC. Fredrikson et al. (1991) previously determined that $25 \%$ of their subsurface (presumably oligotrophic) bacterial isolates utilized less than $10 \%$ of the available BIOLOG ${ }^{\circledR}$ GN substrates. Haack et al. (1995) observed that authentic soil isolates of Bacillus and $\underline{\text { Arthrobacter }}$ sp. produced no positive color changes in BIOLOG $^{\circledR}$ GN plates despite multiple substrate usage by a type strain. In our study, although substrate utilization was restricted, SC clearly grew using several substrates from the carbohydrates, carboxylic acids, and amino acids guilds.

Physiologically active bacteria are required to produce a positive BIOLOG $^{\circledR}$ response. Autochthonous soil bacteria are thought to be slow-growing and/or subject to starvation conditions due to lack of available carbon substrates. Extended starvation limits the ability of these organisms to be isolated in culture as they become dormant and ultimately non-viable. We found that SC from A horizons, but not B horizons, were able to produce a positive response (O.D. > 0.25) on several BIOLOG ${ }^{\circledR}$ substrates. Others (Garland and Mills, 1991; Garland, 1996b) have used BIOLOG ${ }^{\circledR}$ to demonstrate that greater phenotypic richness exists in 
rhizosphere soils, presumably due to the greater variety and availability of root exudate carbon supporting an actively growing bacterial population. Bossio and Scow (1995) found an increase in the metabolic diversity of soil microbial communities with additional carbon inputs. It may be that greater available soil carbon in A horizons of our sites allow the SC population to maintain greater activity and viability, therefore allowing greater substrate utilization in the BIOLOG ${ }^{\circledR}$ system.

It has been proposed that viability may be maintained in the absence of culturability, and viable but non-culturable cells may be able to return to an actively metabolizing state under favorable conditions (McDougald et al., 1998). Cells extracted from the soil may be in a state of metabolic inactivity in order to survive low nutrient availability, especially in B horizon soils. Resuscitation of viable but nonculturable cells may occur when a limited number of viable cells in the dormant population grow after nutrient conditions become more favorable (Morgan et al., 1991; Weichart et al., 1992). Kaprelyants et al. (1994) suggested that viable cells may produce a factor that stimulates the resuscitation of dormant cells. Due to differences in nutrient availability, more viable cells may be present in A compared to B horizon soils. Therefore, following enrichment in the BIOLOG ${ }^{\circledR}$ wells, some A horizon cells may be "resuscitated" and regain their metabolic integrity, while B horizon cells remain dormant. It is unclear whether SC in the B horizon are metabolically dormant and/or physiologically distinct from those in A horizon soils.

Indirect characterization of microbial community structure by functional diversity measurements has been made convenient due to the commercial availability of BIOLOG ${ }^{\circledR}$ microtitre plates. The lack of substrate utilization by the B horizon SC fraction in the present study emphasizes that such functional diversity measurements incompletely characterize the true 
diversity of the actual bacterial populations present. It is probable that most functional diversity studies have characterized only large-celled, fast growing, metabolically-active bacteria. In our study, the BIOLOG ${ }^{\circledR}$ system was capable of at least partial characterization of the SC community found in A horizon soils. Future work on this topic should include attempts to enhance potential recovery of $\mathrm{SC}$ in the $\mathrm{BIOLOG}^{\circledR}$ system. It may be possible to partially resuscitate $\mathrm{SC}$ prior to inoculation into $\mathrm{BIOLOG}^{\circledR}$ plates, thus increasing the functional diversity measurements obtained. Resuscitation coupled with enrichment and growth in BIOLOG $^{\circledR}$ wells may prove a reasonable approach to obtaining additional isolates of previously uncultured species of soil bacteria. 


\section{References}

Bakken, L.R., 1985. Separation and purification of bacteria from soil. Applied and Environmental Microbiology 49, 1482-1487.

Bakken, L.R., Olsen, R.A., 1986. Dwarf cells in soil—a result of starvation of "normal" bacteria, or a separate population? In: Megusar, F., Gantar, M., (Eds), Perspectives in Microbial Ecology: Proceedings of the 4th International Symposium on Microbial Ecology. Slovene Society for Microbiology, Jamnikarjeva.

Bakken, L.R., Olsen, R.A., 1989. DNA-content of soil bacteria of different cell size. Soil Biology \& Biochemistry 21, 789-793.

Biolog, Inc., 1993. Instructions for use of the BIOLOG ${ }^{\circledR}$ GP and GN microplates. Biolog, Inc., Hayward, CA.

Bossio, D.A., Scow, K.M., 1995. Impact of carbon and flooding on the metabolic diversity of microbial communities in soils. Applied and Environmental Microbiology 61, 4043 4050 .

Bottomley, P.J., 1994. Light microscopic methods for studying soil microorganisms. In: Weaver, R.W., Angle, S., Bottomley, P., Bezdicek, D., Smith, S., Tabatabai, A., Wollum, A., (Eds), Methods of Soil Analysis, Part 2. Soil Society of America, Inc., Madison, WI.

Fliermans, C.B., Franck, M.M., Hazen, T.C., Gorden, R.W., 1997. Ecofunctional enzymes of microbial communities in ground water. FEMS Microbiology Reviews 20, 379-389.

Fredrickson, J.K., Balkwill, D.L., Zachara, J.M., Li, S-M.W., Brockman, F.J., Simmons, M.A., 1991. Physiological diversity and distributions of heterotrophic bacteria in deep Cretaceous sediments of the Atlantic coastal plain. Applied and Environmental Microbiology 57, 402-411.

Garland, J.L., 1996a. Analytical approaches to the characterization of samples of microbial communities using patterns of potential C source utilization. Soil Biology and Biochemistry 28, 213-221.

Garland, J.L., 1996b. Patterns of potential C source utilization by rhizosphere communities. Soil Biology and Biochemistry 28, 223-230.

Garland, J.L., 1997. Analysis and interpretation of community-level physiological profiles in microbial ecology. FEMS Microbial Ecology 24, 289-300.

Garland, J.L., Mills, A.L., 1991. Classification and characterization of heterotrophic microbial communities on the basis of patterns of community-level-sole-carbon-source-utilization. Applied and Environmental Microbiology 57, 2351-2359. 
Garland, J.L., Mills, A.L., 1994. A community-level physiological approach for studying microbial communities. In: Ritz, K., Dighton, J., Giller, K.E. (Eds), Beyond the Biomass. John Wiley and Sons, Chichester. pp.85-94.

Haack, S.K., Garchow, H., Klug, M.J., Forney, L.J., 1995. Analysis of factors affecting the accuracy, reproducibility, and interpretation of microbial community carbon source utilization patterns. Applied and Environmental Microbiology 61, 1458-1468.

Holben, W.E., Jansson, J.K., Chelm, B.K., Tiedje, J.M., 1988. DNA probe method for the detection of specific microorganisms in the soil bacterial community. Applied and Environmental Microbiology 54, 703-711.

Kaprelyants, A.S., Mukamolova, G.V., Kell, D.B., 1994. Estimation of dormant Micrococcus $\underline{\text { luteus cells by penicillin lysis and by resuscitation in cell-free spent culture medium at }}$ high dilution. FEMS Microbiology Letters 115, 347-352.

Konopka, A., Oliver, L., Turco, Jr, R.F., 1998. The use of carbon substrate utilization patterns in environmental and ecological microbiology. Microbial Ecology 35, 103-115.

Lindahl, V., 1996. Improved soil dispersion procedures for total bacterial counts, extraction of indigenous soil bacteria, and cell survival. Journal of Microbiological Methods 25, 279286.

Lindahl, V., Aa, K., Olsen, R.A., 1996. Effects on microbial activity by extraction of indigenous cells from soil slurries. FEMS Microbiology Ecology 21, 221-230.

Lindahl, V., Frostegard, A., Bakken, L., Baath, E., 1997. Phospholipid fatty acid composition of size fractionated indigenous soil bacteria. Soil Biology and Biochemistry 29, 1565-1569.

McDougald, D., Rice, S.A., Weichart, D., Kjelleberg, S., 1998. Nonculturability: adaptation or debilitation? FEMS Microbiology Ecology 25, 1-9.

Morgan, J.A.W., Cranwell, P.A., Pickup, R.W., 1991. Survival of Aeromonas salmonicida in lake water. Applied and Environmental Microbiology 57, 1777-1782.

Olsen, R.A., Bakken, L.R., 1987. Viability of soil bacteria: optimization of plate-counting technique and comparison between total counts and plate counts within different size groups. Microbial Ecology 13, 59-74.

Riis, V., Lorbeer, H., Babel, W., 1998. Extraction of microorganisms from soil: evaluation of the efficiency by counting methods and activity measurements. Soil Biology and Biochemistry 30, 1573-1581.

Staddon, W.J., Duchesne, L.C., Trevors, J.T., 1997. Microbial diversity and community structure of postdisturbance forest soils as determined by sole-carbon-source utilization patterns. Microbial Ecology 34, 125-130. 
Torsvik, V., Goksoyr, J., Daae, F.L., 1990. High diversity in DNA of soil bacteria. Applied and Environmental Microbiology 56, 782-787.

Weichart, D., Oliver, J.D., Kjelleberg, S., 1992. Low-temperature induced non-culturability and killing of Vibrio vulnificus. FEMS Microbiology Letters 100, 205-210.

Winding, A., 1994. Fingerprinting bacterial soil communities using Biolog microtiter plates. In: Ritz, K., Dighton, J., Giller, K.E. (Eds), Beyond the Biomass. John Wiley and Sons, Chichester. pp.85-94.

Zak, J.C., Willig, M.R., Moorhead, D.L., Wildman, H.G., 1994. Functional diversity of microbial communities: a quantitative approach. Soil Biology and Biochemistry 26, 1101-1108. 
Table 1. Bacterial numbers in forested and cultivated Guernsey silt loam soil determined by direct microscopic counts.

\begin{tabular}{|c|c|c|c|c|}
\hline \multirow{3}{*}{ Sample } & \multicolumn{4}{|c|}{ Number of cells gram ${ }^{-1}$ dry weight soil } \\
\hline & \multicolumn{2}{|c|}{ A Horizon } & \multicolumn{2}{|c|}{ B Horizon } \\
\hline & $F^{d}$ & $c^{d}$ & $\mathbf{F}$ & C \\
\hline Uncentrifuged $^{\mathrm{a}}$ & $5.31 \times 10^{10}$ & $4.56 \times 10^{10}$ & $3.25 \times 10^{10}$ & $2.56 \times 10^{10}$ \\
\hline Centrifuged $^{b}$ & $9.27 \times 10^{8}$ & $4.63 \times 10^{8}$ & $5.83 \times 10^{8}$ & $2.25 \times 10^{8}$ \\
\hline $\mathbf{L C}^{\mathrm{c}}$ & $2.46 \times 10^{8}$ & $1.27 \times 10^{8}$ & $1.82 \times 10^{8}$ & $6.21 \times 10^{7}$ \\
\hline $\mathbf{S C}^{\mathbf{c}}$ & $5.46 \times 10^{8}$ & $2.89 \times 10^{8}$ & $3.53 \times 10^{8}$ & $2.26 \times 10^{8}$ \\
\hline \multicolumn{5}{|c|}{${ }^{\mathrm{a}}$ Uncentrifuged $=$ counts made before centrifugation at $2500 \mathrm{rev} \mathrm{min}^{-1}$} \\
\hline \multicolumn{5}{|c|}{${ }^{\text {b }}$ Centrifuged $=$ counts made following centrifugation at 2500 rev $\min ^{-1}$} \\
\hline \multicolumn{5}{|c|}{${ }^{\mathrm{C}} \mathrm{LC}$, large cells $(>0.45 \mu \mathrm{m}) ; \mathrm{SC}$, small cells $(<0.45 \mu \mathrm{m})$} \\
\hline${ }^{\mathrm{d}} \mathrm{F}$, forested site & cultivated $s$ & & & \\
\hline
\end{tabular}




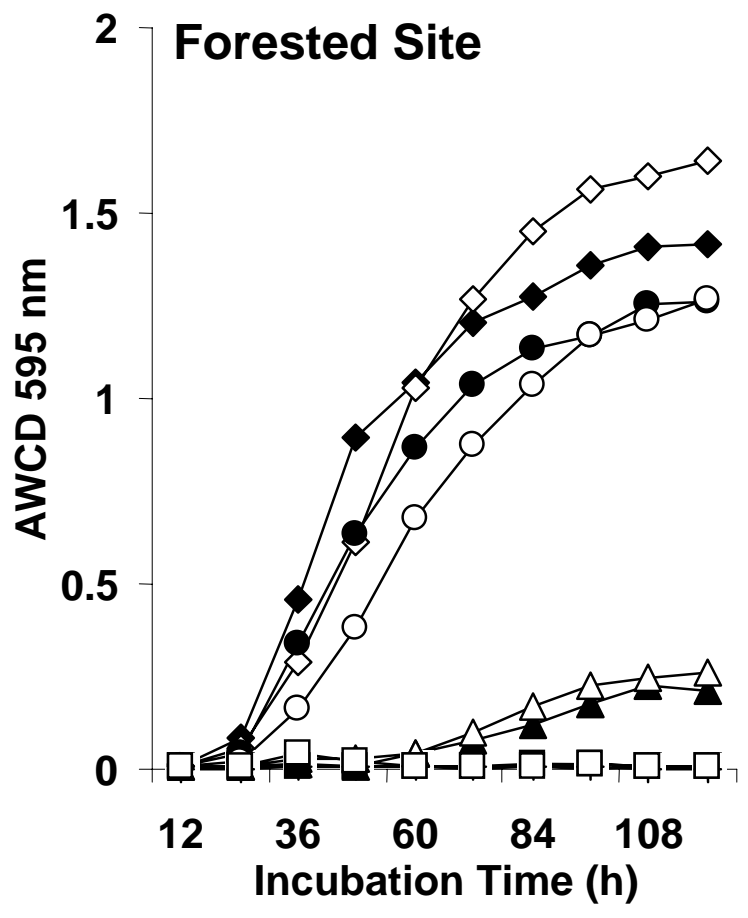

\section{Cultivated Site}

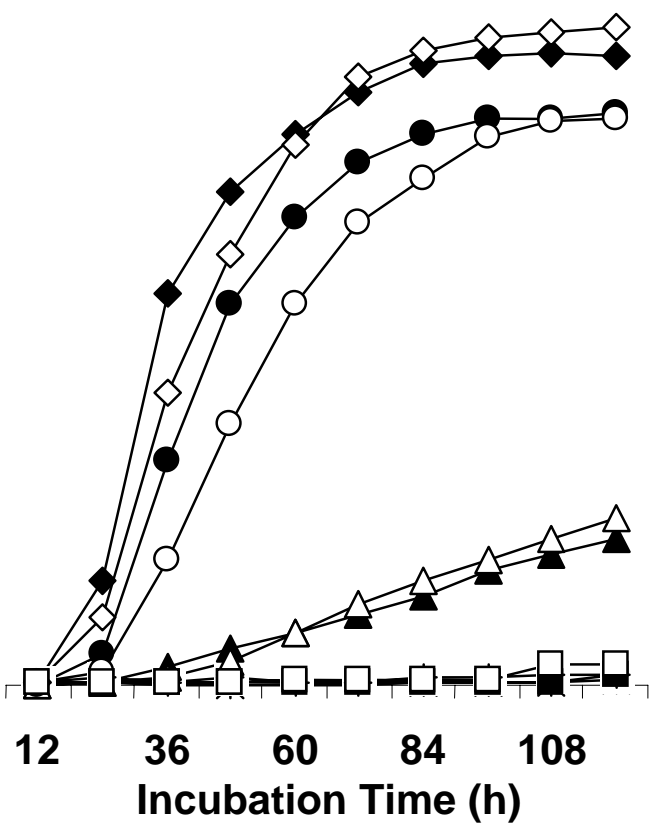

Figure 1. Average well color development (AWCD) from GN and GP BIOLOG plates with time for large (LC) and small (SC) cell size fractions of forested and cultivated sites. Solid symbols represent data taken from GN plates, open symbols represent data taken from GP plates. Symbols represent the following: $\diamond$, A horizon LC; $\triangle$, A horizon SC; $\bigcirc$, B horizon LC; $\square$, B horizon SC. (Note: solid square symbols are obscured by open symbols along the baseline of the figure.) 
Table 2. Bacterial functional diversity indices determined in forested and cultivated Guernsey silt loam soil as determined with GN and GP BIOLOG microtitre plates.

\begin{tabular}{lcrrrrrrrr}
\hline Plate Type & Sample $^{\mathbf{a}}$ & \multicolumn{2}{c}{ Sum $^{\text {of }}$ Activities $^{\mathbf{b}}$} & \multicolumn{2}{c}{ AWCD $^{\mathbf{c}}$} & \multicolumn{2}{c}{ Richness $^{\mathbf{d}}$} & \multicolumn{2}{c}{ Diversity $^{\mathbf{e}}$} \\
GN Plates & & \multicolumn{1}{c}{$\mathbf{F}^{\mathbf{f}}$} & \multicolumn{1}{c}{$\mathbf{C}^{\mathbf{f}}$} & $\mathbf{F}$ & $\mathbf{C}$ & $\mathbf{F}$ & $\mathbf{C}$ & $\mathbf{F}$ & $\mathbf{C}$ \\
& A LC & 114.6 & 144.0 & 1.21 & 1.52 & 79 & 86 & 4.32 & 4.44 \\
& B LC & 98.5 & 121.7 & 1.04 & 1.28 & 67 & 81 & 4.18 & 4.35 \\
& A SC & 7.4 & 13.6 & 0.08 & 0.14 & 10 & 11 & 3.56 & 3.55 \\
& B SC & 0.5 & 0.9 & 0.01 & 0.01 & 0 & 0 & NC & NC \\
& & & & & & & & & \\
& A Plates & 120.1 & 140.9 & 1.26 & 1.48 & 81 & 92 & 4.37 & 4.46 \\
& B LC & 82.8 & 99.1 & 0.87 & 1.04 & 60 & 73 & 4.09 & 4.27 \\
& A SC & 9.7 & 13.8 & 0.10 & 0.14 & 12 & 13 & 3.40 & 3.48 \\
& B SC & 0.8 & 1.2 & 0.01 & 0.01 & 0 & 0 & NC & NC \\
\hline
\end{tabular}

${ }^{\mathrm{a} A}$, A horizon; B, B horizon; LC, large cells $(>0.45 \mu \mathrm{m})$; SC, small cells $(<0.45 \mu \mathrm{m})$

${ }^{\mathrm{b}}$ Average sum of activities $=$ average sum of absorbance values from triplicate plates

${ }^{c}$ Average well color development $($ AWCD $)=$ average sum of activities $/ 95$

${ }^{d}$ Substrate richness $=$ average number of positive wells (absorbance value $>0.25$ )

'Substrate diversity $=-\Sigma \mathrm{pi}(\ln \mathrm{pi})$, where $\mathrm{pi}=$ average absorbance of a single substrate $/$ average sum of activities

${ }^{\mathrm{f}} \mathrm{F}$, forested site; C, cultivated site

$\mathrm{NC}=$ not calculated 

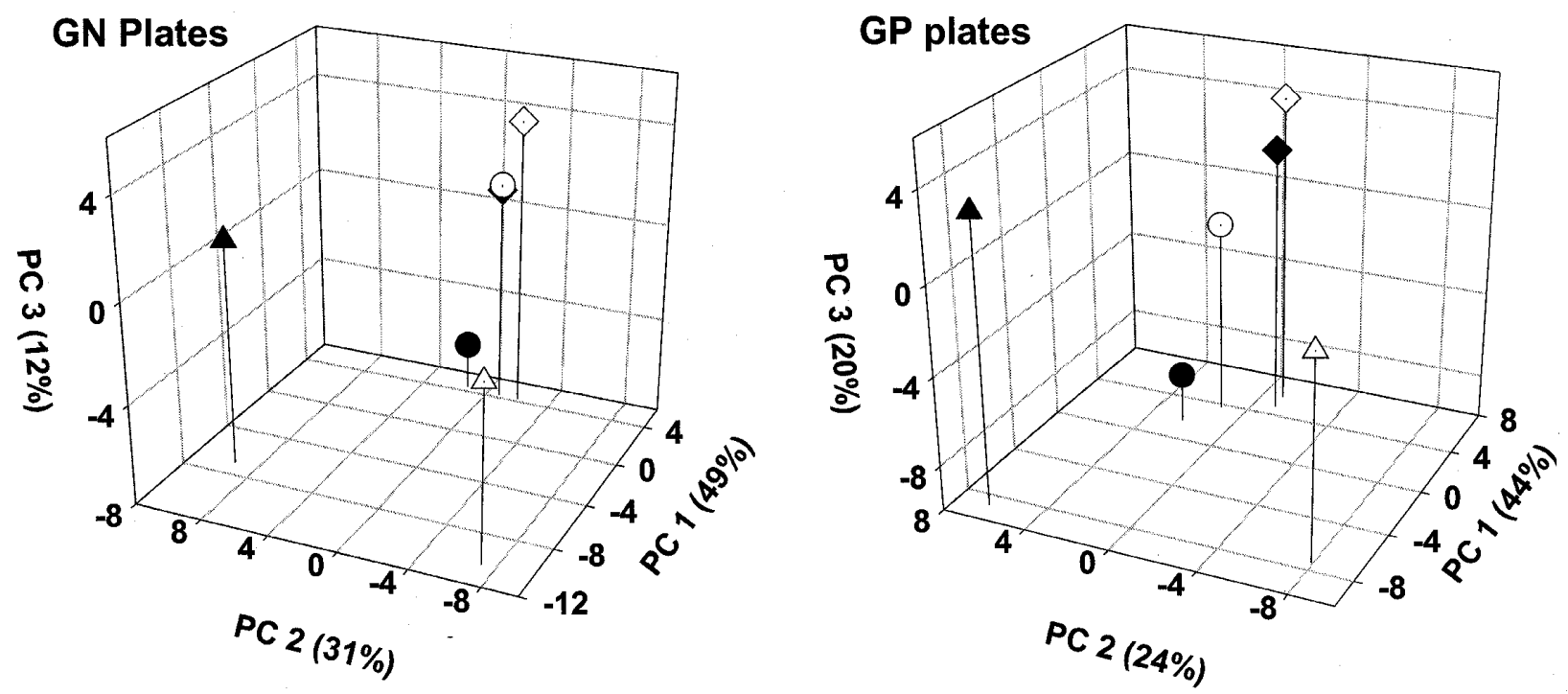

Figure 2. Principle component analyses based on adjusted AWCD (average absorbance value for each substrate divided by AWCD) from GN and GP BIOLOG plates. Values in parentheses indicate the proportion of total variation accounted for by each principle component. Symbols are as follows: $\diamond$, A horizon LC; $\triangle$, A horizon SC; $\bigcirc$, B horizon LC. Cultivated site samples are denoted by open symbols, forested site samples are denoted by solid symbols. 
Table 3. Average richness (absorbance $>0.25$ ) within substrate guilds of $G N$ and GP BIOLOG microtitre plates inoculated with size-fractionated bacteria from forested and cultivated Guernsey silt loam soil.

\begin{tabular}{|c|c|c|c|c|c|c|c|c|c|}
\hline \multirow[b]{3}{*}{ Substrate Guild } & \multirow[b]{3}{*}{ \#GN/\#GP } & \multirow{2}{*}{\multicolumn{4}{|c|}{$\begin{array}{l}\text { LC A horizon } \\
\text { GN }\end{array}$}} & \multicolumn{4}{|c|}{ SC A horizon ${ }^{\mathrm{b}}$} \\
\hline & & & & & & & & & \\
\hline & & $\mathbf{F}^{\mathrm{c}}$ & $C^{c}$ & $\mathbf{F}$ & C & $\mathbf{F}$ & C & $\mathbf{F}$ & C \\
\hline Carbohydrates & $30 / 43$ & 28 & 30 & 37 & 42 & 5 & 5 & 5 & 5 \\
\hline Carboxylic Acids & $24 / 16$ & 16 & 20 & 14 & 16 & 2 & 3 & 4 & 3 \\
\hline Polymers & $5 / 7$ & 5 & 5 & 7 & 7 & 0 & 0 & 0 & 1 \\
\hline Amines/Amides & $6 / 4$ & 4 & 5 & 2 & 4 & 0 & 0 & 0 & 1 \\
\hline Amino Acids & $20 / 8$ & 18 & 18 & 8 & 8 & 2 & 2 & 2 & 2 \\
\hline Miscellaneous & $10 / 17$ & 8 & 8 & 13 & 15 & 1 & 1 & 1 & 1 \\
\hline
\end{tabular}




\section{CHAPTER 2}

Characterization of dilution enrichment cultures obtained from size-fractionated soil bacteria by BIOLOG ${ }^{\circledR}$ substrate utilization patterns and restriction analysis of $16 \mathrm{~S}$ rRNA genes 


\section{Introduction}

Small-celled soil bacteria rarely are obtained in culture, therefore the physiological and ecological function of these numerically abundant organisms is currently a matter of speculation (Bakken and Olsen, 1989). Alternative methods to cultivate and study these fastidious organisms are necessary if we are to gain insight into their metabolic activity in soil. Dilution cultures have proven advantageous in studying small-celled oligotrophic bacteria since dilution of the inoculum retains numerically abundant organisms, while eliminating fast-growing competitors that would typically prevail in enrichment culture (Button et al., 1993). Dilution culture allows the recovery of several types of bacteria from a single inoculum source since shifts in the bacterial population occur, depending on the number and growth-rate of the organisms present at each dilution level. Using a wetland biofilm inoculum, Jackson et al. (1998) detected changes in bacterial genotypes with increasing dilution using denaturing gradient gel electrophoresis of PCR-amplified 16S rRNA. Janssen et al. (1997) isolated a novel anaerobic ultramicrobacterium (cell volume $<0.1 \mu \mathrm{m}^{3}$ ) from anoxic rice paddy soil by utilizing a liquid dilution culture technique.

In previous work, small soil bacteria $(<0.45 \mu \mathrm{m}$ in diameter $)$ exhibited limited substrate use on $\mathrm{BIOLOG}^{\circledR} \mathrm{GN}$ and GP microtitre plates compared to larger cells $(>0.45 \mu \mathrm{m}$ in diameter), despite similar inoculum densities (K. Kinneer, 1999, MS Thesis Chapter 1, WVU). Differences in the physiological state of these size-fractionated bacteria may have accounted for the observed differences in substrate utilization. Small cells from A horizon soils were able to utilize several

carbon substrates in the BIOLOG $^{\circledR}$ microtitre plates, however those from B horizon soils utilized none. It was unclear whether small cells from B horizon soils were metabolically dormant and/or physiologically distinct from those in A horizon soils. 
In the present study, the dilution culture technique was employed in an attempt to enrich for small-celled bacteria from A and B horizons of forested and cultivated sites of a Guernsey silt-loam soil. Dilution cultures were used to inoculate BIOLOG ${ }^{\circledR} \mathrm{GN}$ microtitre plates to investigate whether the activity of small-celled bacteria was stimulated by enrichment. Using $\mathrm{BIOLOG}^{\circledR}$, we examined changes in functional diversity in the bacterial community among flasks of increasing dilution. In addition, restriction digestion of PCR-amplified 16S rRNA genes was employed to compare the genetic diversity of the bacterial communities in the dilution flasks.

\section{Materials and Methods}

\section{Study sites and sampling procedures}

Two sites were studied: a cultivated site, which has undergone regular tillage since 1976; and, a forested site, a naturally wooded area dominated by deciduous trees. The soil type at both sites is a Guernsey silt loam (fine, mixed, mesic Aquic Hapludalfs). Both sites are located at the West Virginia University Plant Sciences Farm in Morgantown, WV $\left(39.63^{\circ} \mathrm{N}, 79.95^{0} \mathrm{~W}\right)$.

Multiple core samples were taken from each site by using a split-core soil sampler. Samples from the A and B horizon were collected on site and placed into separate plastic bags

for immediate transport to the laboratory, where they were individually bulked and coarse-sieved (4.75 mm mesh size). All samples were stored at field moisture in sealed plastic bags and were refrigerated at $4 \mathrm{C}$ until use.

\section{Sample preparation}

For each of the four soil samples, $50 \mathrm{~g}$ soil, $200 \mathrm{ml}$ Winogradsky's salt solution $(5.0 \mathrm{~g}$ $\mathrm{K}_{2} \mathrm{HPO}_{4}, 5.0 \mathrm{~g} \mathrm{MgSO}_{4} \cdot 7 \mathrm{H}_{2} \mathrm{O}, 2.5 \mathrm{~g} \mathrm{NaCl}, 0.05 \mathrm{~g} \mathrm{Fe}_{2}\left(\mathrm{SO}_{4}\right)_{3} \cdot \mathrm{H}_{2} \mathrm{O}, 0.05 \mathrm{~g} \mathrm{Mn}_{2}\left(\mathrm{SO}_{4}\right)_{3} \cdot 4 \mathrm{H}_{2} \mathrm{O}$, 


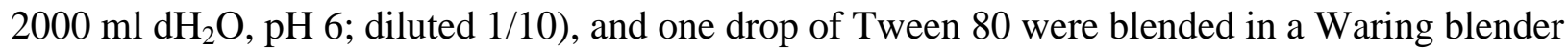
for three one-minute intervals with intermittent cooling in an ice bath. This was repeated until six $250 \mathrm{ml}$ centrifuge bottles (Nalgene ${ }^{\circledR}$, polyethylene) per horizon and study site were filled with soil homogenate. Large soil particles were removed by centrifugation at $2500 \mathrm{rev}^{-1}{ }^{-1}$ for 15 min at $4 \mathrm{C}$ in a Sorvall ${ }^{\circledR}$ RC-5B Refrigerated Superspeed Centrifuge and a Sorvall ${ }^{\circledR}$ GSA rotor. The resulting supernatants from each site and soil horizon were pooled and added to 500 ml Winogradsky's salt solution.

To separate bacterial cells according to size, each cell solution was passed through 0.45 $\mu \mathrm{m}$ Millipore HA filters. The filtrate contained bacterial cells smaller than $0.45 \mu \mathrm{m}$ in diameter and represented the small cell (SC) fraction. Large cells (LC) greater than $0.45 \mu \mathrm{m}$ in diameter were collected by washing material from the surface of the filters, by placing them into Petri plates containing Winogradsky's salt solution and shaking on a rotary shaker (Lab-line orbit shaker) at $110 \mathrm{rev} \min ^{-1}$ for 15-20 min. A sterile paintbrush (5/32" diameter) was used to brush off any remaining cells from the surface of the filters.

To collect cells, LC and SC samples were centrifuged at 10,000 rev $\min ^{-1}, 4 \mathrm{C}$, for 25 min. Supernatants were discarded, and cells were resuspended in $200 \mathrm{ml}$ Winogradsky's salt solution. The cells were then washed three times, to remove soil particles and dissolved carbon, by centrifugation in the same manner.

\section{Inoculation of dilution cultures}

Two separate experiments were performed: the first included LC and SC from the A horizon of both study sites; and, the second included SC only from A and B horizons of both study sites. Prior to inoculation, washed cells were equalized to $95 \% \mathrm{~T}\left(\mathrm{~A}_{595}=0.02\right)$ on a spectrophotometer (Bausch and Lomb Spectronic 20). Ten $\mathrm{ml}$ of each sample were transferred 
to a $250 \mathrm{ml}$ Erlenmeyer flask containing $90 \mathrm{ml}$ of 1/10 R2A broth (0.05 g Bacto Yeast Extract, 0.05 g Bacto Protease Peptone No.3, 0.05 g Bacto Casamino Acids, 0.05 g Bacto Dextrose, 0.05 $\mathrm{g}$ soluble starch, $0.03 \mathrm{~g}$ potassium phosphate, dibasic, $0.005 \mathrm{~g}$ magnesium sulfate, in $1 \mathrm{~L}$ distilled $\mathrm{H}_{2} \mathrm{O}$ ). A serial ten-fold dilution was performed, resulting in a series of $10^{-1}$ through $10^{-6}$ dilutions in this medium.

Following inoculation, all flasks were incubated on a shaker $\left(200 \mathrm{rev} \mathrm{min}^{-1}\right.$; Series 25 Incubator Shaker, New Brunswick Scientific Co.) set at $25 \mathrm{C}$ for one week. Aliquots (1 ml) from each turbid flask were transferred to fresh medium and allowed to incubate for three additional days, at which time they were harvested prior to inoculation of $\mathrm{BIOLOG}^{\circledR}$ microtitre plates.

\section{BIOLOG ${ }^{\circledR}$ inoculation}

Prior to cell harvest, the turbidity of each flask was determined. Each dilution culture was then poured into a sterile $250 \mathrm{ml}$ centrifuge bottle (Nalgene) and centrifuged at 10,000 rev min ${ }^{-1}$, $4 \mathrm{C}$, for $25 \mathrm{~min}$. The supernatant was discarded, cells were washed and resuspended in fresh Winogradsky's salt solution, and the centrifugation process was repeated two additional times. Recovered cells were then suspended in Winogradsky's salt solution and adjusted to $92 \% \mathrm{~T}$ $\left(\mathrm{A}_{595}=0.04\right)$. Suspensions were then inoculated into GN BIOLOG ${ }^{\circledR}$ plates, $100 \mu \mathrm{L}$ per well. The plates were incubated at $25 \mathrm{C}$ and were read every $12 \mathrm{~h}$ to monitor color development.

In the second experiment (SC only, A and B horizon soil), cell suspensions were collected for molecular analysis as well as for BIOLOG ${ }^{\circledR}$ inoculation. Cells were washed with saline $(0.85 \% \mathrm{NaCl})$ instead of Winogradsky's salt solution to eliminate excess magnesium that would interfere with subsequent PCR. Washed and centrifuged pellets were resuspended in $3 \mathrm{ml}$ saline of which $1 \mathrm{ml}$ was transferred to an Eppendorf tube and frozen at $-60 \mathrm{C}$ until later use. 
The remaining cell suspension was diluted to $92 \% \mathrm{~T}\left(\mathrm{~A}_{595}=0.04\right)$ and inoculated into $\mathrm{GN}$ BIOLOG $^{\circledR}$ plates as described above.

\section{Cell measurement}

Cells from each turbid enrichment culture were transferred to a clean microscope slide and combined with an equal volume of nigrosin to prepare negative stains. Measurements were made from ten random fields of view by using a compound microscope (Nikon Eclipse E600) equipped with an ocular micrometer.

\section{Amplified ribosomal DNA restriction analysis (ARDRA)}

PCR reaction mixtures contained $50 \mathrm{mM} \mathrm{KCl,} 10 \mathrm{mM}$ Tris- $\mathrm{HCl}(\mathrm{pH} 9), 1.5 \mathrm{mM} \mathrm{MgCl}_{2}$, 0.1\% Triton X-100, $1.25 \mathrm{mM}$ each of deoxynucleotide triphosphates (dATP, dCTP, dGTP, dTTP; Promega), 2.5 U Taq DNA polymerase (Promega), $1 \mu \mathrm{M}$ each of oligonucleotide primers (GIBCO BRL Custom Primers, described below) and $1 \mu \mathrm{L}$ or $5 \mu \mathrm{L}$ diluted cells as prepared for $\mathrm{BIOLOG}^{\circledR}$ inoculation above in a total volume of $50 \mu \mathrm{L}$. In preliminary experiments it was determined that following equalization of turbidity to $92 \% \mathrm{~T}$, samples containing $1 \mu \mathrm{L}$ of cells (among several concentrations tested) provided maximal PCR product (data not shown). However, for six samples, amplifications had to be repeated with $5 \mu \mathrm{L}$ of cells to obtain sufficient product to conduct restriction analyses. The sequence of the forward primer pA was 5'-AGA GTT TGA TCC TGG CTC AG-3' and the sequence of the reverse primer pH was 5'AAG GAG GTG ATC CAG CCG CA-3' (Ovreas and Torsvik, 1998). Together, these prime amplification of nearly full-length $16 \mathrm{~S}$ rDNA and a portion of 23S rDNA (256f-1930r) (Ovreas and Torsvik, 1998; Weisburg et al., 1991). Reaction mixtures were subjected to a thermalcycling regime (in a PTC-100 Programmable Thermal Controller, MJ Research, Inc.) consisting of an initial denaturization at $94 \mathrm{C}$ for $3 \mathrm{~min}$, followed by 35 cycles of $94 \mathrm{C}$ for $1 \mathrm{~min}, 54 \mathrm{C}$ for 1 
min, and $72 \mathrm{C}$ for $2 \mathrm{~min}$. Negative controls were included with no addition of template DNA. Eight $\mu \mathrm{L}$ of the PCR products were analyzed on $1 \%(w / v)$ agarose gels (Agarose SFR, Midwest Scientific) to check for amplification of a band of the expected size ( 1600 bp) exclusively. Appropriate dilutions of PCR products were digested with Sau 3AI or Rsa I in buffers provided by the manufacturer (New England Biolabs). Products of digestion were separated by electrophoresis through $2 \%$ agarose SFR gels in $0.5 \mathrm{x}$ TBE (45mM Tris-borate, $1 \mathrm{mM}$ EDTA), stained with ethidium bromide, and photographed while exposed to ultraviolet light.

\section{Data analysis}

For the molecular data, pairwise comparisons of the band patterns were manually performed, and a matrix (presence-absence for each band) constructed. From this matrix, a similarity index was calculated according to the formula

$$
\mathrm{S}=2 * \mathrm{n}_{\mathrm{ab}} /\left(\mathrm{n}_{\mathrm{a}}+\mathrm{n}_{\mathrm{b}}\right)
$$

where $n_{a}$ and $n_{b}$ represent the total number of bands present in lanes a and $b$, respectively, and $n_{a b}$ is the number of bands which are shared by both lanes (Weising et al., 1995). From the similarity matrix, a distance matrix was calculated using $\mathrm{D}=1-\mathrm{S}$ as distance values. Data were analyzed with the Phylogeny Inference Package (PHYLIP) (Felsenstein, 1993). The UPGMA (Unweighted Pair Group Maximum Averages) method was used to establish relationships among samples based on the distance matrix data. For all other analyses, data were analyzed with JMP Statistical Software (SAS Institute, Inc.).

\section{Results}

SC obtained from more highly dilute enrichment cultures of A horizon soils produced substrate utilization patterns in $\mathrm{BIOLOG}^{\circledR}$ GN plates that were distinct both from all enrichments 
of LC and from SC obtained in less dilute enrichments. LC from the forested and cultivated sites utilized 56 to $89 \%$ and 76 to $97 \%$ of the available BIOLOG carbon substrates, respectively

(Table 1). In contrast, SC from the forested site and cultivated sites positively utilized 5 to $80 \%$ and 19 to $78 \%$ of the available substrates. Substrate richness decreased with increasing dilution in the SC enrichment cultures. SC in the early dilution flasks $\left(10^{-1}\right)$ utilized a similar number of substrates as LC. A similar trend was evident in calculated functional diversity, where SC in the early dilutions exhibited values nearly equal to those of the LC (Table 1). However, as with substrate richness, both the SC diversity index and AWCD decreased with increasing dilution. Differences were noted in the SC response from cultivated compared with forested soils. In general, greater values for substrate richness, AWCD, and diversity were observed at any given dilution of the cultivated compared with forested soil.

Principle-component analysis (PCA) performed using normalized values of AWCD provided further evidence that dilution-enrichment of size-fractionated soil bacteria resulted in metabolically distinct sub-populations. PCA separated samples according to inoculum dilution and cell size at both study sites (Figure 1). Consistent with data in Table 1, SC obtained from the least dilute enrichments usually grouped with LC. All dilutions of LC from the cultivated site grouped similarly, however the most dilute enrichment of LC from the forested site $\left(10^{-6}\right)$ grouped with SC (Figure 1). At both sites, SC obtained from the most dilute enrichments were clearly separated from LC and all other SC samples.

Substrate utilization in $\mathrm{BIOLOG}^{\circledR} \mathrm{GN}$ plates by $\mathrm{SC}$ isolated from A and B horizon soils of both study sites were compared in a second dilution-enrichment experiment. Results from A horizon soils were similar to those from the preceding experiment, although slightly greater substrate utilization was observed in the most dilute enrichments from the cultivated site. In 
general, at any given inoculum dilution SC from A horizon soil utilized a greater number of substrates than did SC from the B horizon (Table 2). Greatest substrate richness, AWCD, and diversity values were observed in the least dilute B horizon enrichments followed by generally decreasing values with increasing inoculum dilution. Positive enrichment (turbidity/growth) of B horizon SC occurred with 100-fold more dilute inoculum in the cultivated compared with the forested site (Table 2).

Consistent with information presented in Table 2, PCA separated data by soil horizon and inoculum dilution (Figure 2). A and B horizons of the cultivated site were clearly separated along PC 2. Soil horizons at the forested site separated along both PC1 and PC2. The least dilute B horizon enrichment generally grouped most closely with A horizon samples. More dilute B horizon samples grouped distinctly from the A horizon at both sites.

Cells from these same SC dilution-enrichment cultures were used as a source of template DNA in PCR to amplify the 16S rRNA genes (rDNA) from the resulting SC bacterial community. The PCR products were then digested with restriction enzymes and their restriction fragment length polymorphisms (RFLP) compared. Examination of the band patterns from Sau3AI and RsaI digestions indicated that the dilution culture technique successfully enriched distinct bacterial sub-populations from individual soil samples (Figure 3). The appearance of novel bands in cultures started with more dilute inocula indicates that, through dilution, certain species were released from competition. Summing and averaging band lengths from the two gels suggests that PCR successfully amplified rDNA from between 1 to 4 bacterial species per dilution flask, based on a 1600 base-pair length for the amplified 16S rRNA region (Hartmann et al., 1997). 
The unweighted pair group maximum average (UPGMA) method was used to establish relationships among samples based on a distance matrix calculated from combined Sau3AI and Rsal band patterns. Relationships established by this method indicated that enrichment in dilution cultures resulted in SC populations that varied by study site, soil horizon, and dilution (Figure 4). In general, A and B horizon samples were clustered across sites, with the exception of the cultivated A horizon $10^{-4}$ and $10^{-5}$ enrichments, which grouped with the B horizon samples. Two dilution cultures from the cultivated site (A horizon $10^{-2}$ and B horizon $10^{-2}$ ) were separated from the primary A and B horizon clusters because they were dominated by individual organisms that were not significant components of the other dilution cultures (Figure 3). The forested site A horizon samples were similar to each other but distinct from those of the forested B horizon. Cultivated site A horizon samples of increasing dilution were distinct from each other, and were intermingled with cultivated B horizon samples. Dilution-enrichment resulted in a larger number of distinct RFLP patterns in the cultivated compared with the forested site.

\section{Discussion}

In a previous study (K. Kinneer, MS Thesis Chapter 1, WVU), substrate utilization patterns generated in $\mathrm{BIOLOG}^{\circledR}$ microtitre plates differed between SC and LC bacteria extracted directly from soil. These differences were readily apparent despite a similar inoculum density for both cell size fractions. In general, the rate and extent of substrate utilization was greatly restricted for the SC compared with the LC size fraction. It may be that SC grew less readily in the enrichment conditions of a BIOLOG ${ }^{\circledR}$ microtitre plates than did LC. These data are consistent with previous studies demonstrating that SC are difficult to grow in culture (Bakken and Olsen, 1986). Among several possible explanations, difficulty in culturing SC may be due to 
dormancy brought on by prolonged starvation of slow-growing autochthonous and sometimes oligotrophic soil bacteria. In this study, we attempted to use dilution of the SC and LC bacterial community to partition inocula according to their numerical prevalence. The diluted inocula were then enriched in a low nutrient medium in an attempt to stimulate growth and recovery of members of the SC bacterial community.

Compared with our previous study, substrate utilization by both LC and SC was stimulated by enrichment in dilution culture. In the present study, we found that following enrichment A horizon SC from the least dilute enrichment cultures utilized a nearly equal number of substrates as LC. However, SC from the most dilute enrichments remained metabolically distinct from LC. Inspection of AWCD with time demonstrated no apparent lag period prior to color development in the positive microtitre wells (data not shown). Presumably, the lag period represents the amount of time needed for cells to reach the $10^{8}$ cells $\mathrm{ml}^{-1}$ density required for color development to begin in a BIOLOG ${ }^{\circledR}$ well (Garland and Mills 1991, Haack et al., 1995). Konopka et al. (1998) suggested that color development is dominated by bacteria in relatively high numbers initially, or those with high maximum growth rates. Lack of a lag period in our data may indicate that either cells were inoculated at a density near $10^{8}$ cells $\mathrm{ml}^{-1}$, or they were in a state of exponential growth at the time of inoculation.

SC from the A horizon of both study sites were previously shown to provide detectable patterns of substrate utilization on the $\mathrm{BIOLOG}^{\circledR}$ plates (K. Kinneer, MS Thesis Chapter 1, WVU). However, SC bacteria from B horizon soils failed to utilize any of the available carbon substrates, suggesting that they were metabolically dormant and/or physiologically distinct from small cells of A horizon soils. Following dilution-enrichment in the present study, B horizon SC of both study sites exhibited activity rivaling that of A horizon SC. These data suggest that 
enrichment in a low-nutrient medium (1/10 strength R2A broth) allowed some B horizon SC to regain their ability to metabolize carbon substrates. It has been proposed that viability may be maintained in the absence of culturability, and viable but non-culturable cells may be able to return to an actively metabolizing state under favorable conditions (McDougald et al., 1998). This phenomenon may explain why B horizon SC exhibited activity in the $\mathrm{BIOLOG}^{\circledR}$ wells only after enrichment in dilution culture. Cells extracted from the soil may be in a state of metabolic inactivity in order to survive low nutrient availability, especially in B horizon soils. Following enrichment, these cells may be 'resuscitated' and regain their metabolic integrity, resulting in an increase in AWCD and substrate richness in $\mathrm{BIOLOG}^{\circledR}$ plates. Cell measurements taken after enrichment indicated that SC increased in length compared to measurements taken before enrichment (data not shown). This larger size may be the result of growth and increased activity by SC while in the presence of increased nutrient availability.

Shifts in substrate richness, AWCD, and diversity indicated changes in the bacterial community among dilution flasks. Principle component analysis of A horizon LC and SC samples from both study sites revealed that the lowest SC dilution $\left(10^{-1}\right)$ grouped with LC samples, while higher SC dilutions were grouped apart from LC (see Figure 1). These data suggest that SC found in the early dilution flasks belong to a similar population as LC, while the numerically-dominant SC found in the highest dilution flasks were a unique community, metabolically distinct from LC. Differences in the SC bacterial community among A and B horizon were also apparent from PCA (see Figure 2). Data suggest that the most competitive, culturable B horizon SC from the least dilute enrichments are similar to cells from the A horizon. However, the most numerically-dominant B horizon SC found in the most dilute enrichments appear to be distinct from the SC community in the A horizon. 
Analysis of PCR-amplified 16S rRNA genes indicated that the dilution culture enriched for genetically distinct populations of SC from A and B horizon soils of both study sites. The number of SC species per dilution flask estimated from Sau3AI and RsaI band lengths was low, ranging from 1 to 4 species per flask. There are several potential explanations for this low species number. It is possible that only a few species of SC bacteria were able to grow in the dilution culture due to nutritional factors, or that only a few species had a sufficient growth rate to prevail in the competitive conditions imposed by enrichment culture. Of the SC able to grow in culture, perhaps only a few species reached population densities high enough to be detected by PCR amplification and EtBr staining. [The detection limit for EtBr-stained PCR products ranges from $10^{3}$ to $10^{4}$ cells (Pepper, 1997).] In this case, only the most competitive members of the community in each dilution flask would be detected, regardless of the actual number of species present. Restriction fragments of nearly equal size are often interpreted as identical bands when band scoring (Weising et al., 1995). Therefore, several species may be contained in each flask, but may give similar restriction fragments, resulting in an underestimation of species content per flask. Moreover, highly conserved regions of the rDNA may give identical-sized fragments from several different species. For example, inspection of the RsaI restriction products revealed a 150-bp band common to all SC samples analyzed, regardless of soil horizon or dilution. Because this small fragment is the only fragment in common among all lanes that contain it, we conclude that it represents a highly conserved region of DNA (rather than a species common to all cultures). By counting this fragment only once (as we did) we underestimate the total length of DNA present. Finally, the choice of primer used for PCR amplification can greatly affect the outcome of an RFLP analysis. "Universal" primers do not unequivocally amplify all 16S rRNA genes present in a sample (Fuhrman, 1997). However, the bacterial primers used in this study 
were reported to amplify nearly full-length 16S rDNA and 23S rDNA (Ovreas and Torsvik, 1998), and were capable of amplifying a wide variety of bacterial taxa (Weisburg et al., 1991). Differences in annealing temperature and quantity and quality of target DNA may affect the specificity and utility of the primer utilized.

Both the BIOLOG ${ }^{\circledR}$ system and ARDRA analysis suggest that enrichment in dilution culture resulted in distinct communities with increasing dilution. Santegoeds et al. (1996) and Jackson et al. (1998) also found changes in the species composition of enrichment cultures throughout the dilution series. Like Jackson et al. (1998), we found bands in higher dilution flasks that were not present in the lowest dilution flasks (see Figure 3) suggesting that dilution cultures select for different types of bacteria by minimizing competitive exclusion.

Analysis of RFLP data by UPGMA resulted in a clear separation of forested A and B horizon samples, while cultivated A and B horizon samples were often grouped together. The overlap in species composition among soil horizons at the cultivated site may be due in part to tillage, which would break up A and B horizon soils and mix them together. At the undisturbed forested site, A and B horizons would not be mixed and therefore, the bacterial communities are more likely to remain distinct from each other.

A great number of as yet uncultured bacterial species exist unstudied in even the most common of soils. Functional diversity measurements by BIOLOG ${ }^{\circledR}$ microtitre plates incompletely characterize the true bacterial diversity of soil samples, but have proved useful in operational comparisons between sites (Konopka et al., 1998). Our studies indicate that a limited number of SC bacteria can grow in $\mathrm{BIOLOG}^{\circledR}$ plates when directly inoculated from soil. Preenrichment of the SC bacterial fraction increased growth in BIOLOG ${ }^{\circledR}$ plates, particularly of cells from our B horizon samples. Substrate utilization patterns obtained from BIOLOG ${ }^{\circledR}$ 
microtitre plates proved to be a convenient method to assess the functional diversity of dilution enrichment cultures obtained from size fractionated soil bacteria. Genetic diversity estimates by ARDRA confirmed the community changes indicated by changes in carbon utilization. 


\section{References}

Bakken, L.R., Olsen, R.A., 1986. Dwarf cells in soil—a result of starvation of "normal” bacteria, or a separate population? In: Megusar, F., Gantar, M. (Eds), Perspectives in Microbial Ecology: Proceedings of the $4^{\text {th }}$ International Symposium on Microbial Ecology. Slovene Society for Microbiology, Jamnikarjeva.

Bakken, L.R., Olsen, R.A., 1989. DNA-content of soil bacteria of different cell size. Soil Biology and Biochemistry 21, 789-793.

Button, D.K., Schut, F., Quang, P., Martin, R., Robertson, B.R., 1993. Viability and isolation of marine bacteria by dilution culture: theory, procedures, and initial results. Applied and Environmental Microbiology 59, 881-891.

Felsenstein, J., 1993. PHYLIP (Phylogeny Inference Package) version 3.5c. Distributed by the author. Department of Genetics, University of Washington, Seattle.

Fuhrman, J.A., 1997. Community structure: bacteria and archaea. In: Hurst, C.J., Knudsen, G.R., McInerney, M.J., Stetzenbach, L.D., Walter, M.V. (Eds), Manual of Environmental Microbiology. ASM Press, Washington D.C.

Garland, J.L., Mills, A.L., 1991. Classification and characterization of heterotrophic microbial communities on the basis of patterns of community-level sole-carbon-source utilization. Applied and Environmental Microbiology 57, 2351-2359.

Haack, S.K., Garchow, H., Klug, M.J., Forney, L.J., 1995. Analysis of factors affecting the accuracy, reproducibility, and interpretation of microbial community carbon source utilization patterns. Applied and Environmental Microbiology 61, 1458-1468.

Hartmann, A., Abmus, B., Kirchhof, G., Schloter, M., 1997. Direct approaches for studying soil microbes. In: van Elsas, J.D., Trevors, J.T., Wellington, E.M.H. (Eds), Modern Soil Microbiology. Marcel Dekker, Inc., New York.

Jackson, C.R., Roden, E.E., Churchill, P.F., 1998. Changes in bacterial species composition in enrichment cultures with various dilutions of inoculum as monitored by denaturing gradient gel electrophoresis. Applied and Environmental Microbiology 64, 5046-5048.

Janssen, P.H., Schuhmann, A., Morshel, E., Rainey, F.A., 1997. Novel anaerobic ultramicrobacteria belonging to the Verrucomicrobiales lineage of bacterial descent isolated by dilution culture from anoxic rice paddy soil. Applied and Environmental Microbiology 63, 1382-1388.

Konopka, A., Oliver, L., Turco, Jr., R.F., 1998. The use of carbon substrate utilization patterns in environmental and ecological microbiology. Microbial Ecology 35, 103-115. 
McDougald, D., Rice, S.A., Weichart, D., Kjelleberg, S., 1998. Nonculturability: adaptation or debilitation? FEMS Microbiology Ecology 25, 1-9.

Ovreas, L., Torsvik, V., 1998. Microbial diversity and community structure in two different agricultural soil communities. Microbial Ecology 36, 303-315.

Pepper, I.L., 1997. PCR: applications for plant and soil microbes. In: Hurst, C.J., Knudsen, G.R., McInerney, M.J., Stetzenbach, L.D., Walter, M.V. (Eds), Manual of Environmental Microbiology. ASM Press, Washington D.C.

Santegoeds, C.M., Nold, S.C., Ward, D.M., 1996. Denaturing gradient gel electrophoresis used to monitor the enrichment culture of aerobic chemoorganotrophic bacteria from a hot spring cyanobacterial mat. Applied and Environmental Microbiology 62, 3922-3928.

Schut, F., DeVries, E.J., Gottschal, J.C., Robertson, B.R., Harder, W., Prins, R.A., Button, D.K., 1993. Isolation of typical marine bacteria by dilution culture: growth, maintenance, and characteristics of isolates under laboratory conditions. Applied and Environmental Microbiology 59, 2150-2160.

Torsvik, V., Goksoyr, J., Daae, F.L., 1990. High diversity in DNA of soil bacteria. Applied and Environmental Microbiology 56, 782-787.

Weisburg, W.G., Barns, S.M., Pelletier, D.A., Lane, D.J., 1991. 16S ribosomal DNA amplification for phylogenetic study. Journal of Bacteriology 173, 697-703.

Weising, K., Nybom, H., Wolff, K., Meyer, W., 1995. DNA fingerprinting in plants and fungi. CRC Press, Boca Raton. 
Table 1. Functional diversity indices determined in A horizon forested and cultivated Guernsey silt loam soil using GN BIOLOG plates inoculated with large and small cells enriched in dilution culture.

\begin{tabular}{lrrrrrrrr}
\hline Sample $^{\mathbf{a}}$ & \multicolumn{2}{c}{ Sum of $^{\text {Activities }}$} & \multicolumn{2}{c}{ AWCD $^{\mathbf{c}}$} & \multicolumn{2}{c}{ Richness $^{\mathbf{d}}$} & \multicolumn{2}{c}{ Diversity $^{\mathbf{e}}$} \\
\hline & \multicolumn{1}{c}{$\mathbf{F}^{\mathbf{f}}$} & $\mathbf{C}^{\mathbf{f}}$ & $\mathbf{F}$ & $\mathbf{C}$ & $\mathbf{F}$ & $\mathbf{C}$ & $\mathbf{F}$ & $\mathbf{C}$ \\
LC 10-1 & 98.8 & 135.4 & 1.04 & 1.43 & 78 & 88 & 4.32 & 4.42 \\
LC 10-2 & 107.2 & 153.8 & 1.13 & 1.62 & 80 & 92 & 4.34 & 4.23 \\
LC 10-3 & 106.5 & ND & 1.12 & ND & 85 & ND & 4.37 & ND \\
LC 10-4 & 102.0 & 132.2 & 1.07 & 1.39 & 77 & 86 & 4.29 & 4.41 \\
LC 10-5 & 86.2 & 94.0 & 0.91 & 0.99 & 70 & 72 & 4.17 & 4.23 \\
LC 10-6 & 34.1 & 131.6 & 0.36 & 1.39 & 53 & 80 & 4.13 & 4.35 \\
SC 10-1 & 100.1 & 114.9 & 1.05 & 1.21 & 76 & 74 & 4.29 & 4.27 \\
SC 10-2 & 59.5 & 48.8 & 0.63 & 0.51 & 56 & 51 & 4.01 & 4.06 \\
SC 10-3 & 74.8 & 49.8 & 0.79 & 0.52 & 50 & 54 & 3.95 & 4.18 \\
SC 10-4 & 8.2 & 25.6 & 0.09 & 0.27 & 6 & 21 & 3.85 & 4.02 \\
SC 10-5 & 7.5 & 41.2 & 0.08 & 0.43 & 8 & 54 & 3.23 & 4.14 \\
SC 10-6 & 4.6 & 18.9 & 0.05 & 0.20 & 5 & 18 & 3.57 & 3.96 \\
\hline ND
\end{tabular}

$\mathrm{ND}=$ not determined because of color development in control well.

aLC, large cells $(>0.45 \mu \mathrm{m})$; SC, small cells $(<0.45 \mu \mathrm{m}) ; 10-1$ to $10-6$ indicate dilution

${ }^{\mathrm{b}}$ Average sum of activities = average sum of absorbance values from triplicate plates

${ }^{\mathrm{c}}$ Average well color development (AWCD) = average sum of activities / 95

'Substrate richness = average number of positive wells (absorbance value $>0.25$ )

${ }^{\mathrm{e} S u b s t r a t e}$ diversity $=-\Sigma \mathrm{pi}(\mathrm{In} \mathrm{pi})$, where $\mathrm{pi}=$ average absorbance of a single

substrate/average sum of activities

${ }^{\mathrm{f}} \mathrm{F}$, forested site; C, cultivated site 

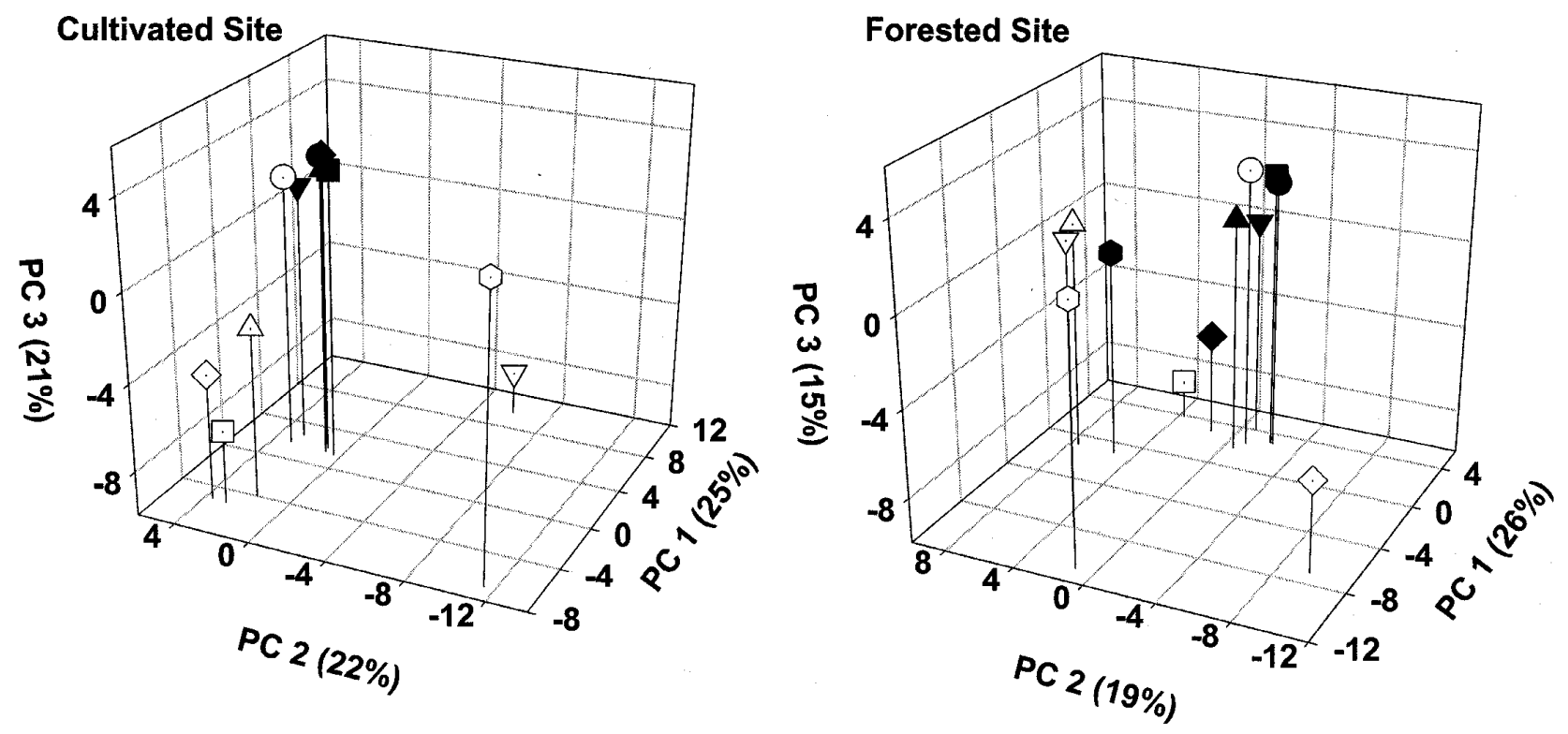

Figure 1. Principle component analyses of large small cells extracted from A horizons of forested and cultivated Guernsey silt loam soil and enriched in dilution culture. Numbers in parentheses indicate the percent of variation accounted for by each principle component. Symbols are as follows: $\bigcirc, 10-1$ dilution; $\square, 10-2$ dilution; $\triangle$, 10-3 dilution; $\nabla, 10-4$ dilution; $\diamond, 10-5$ dilution; $\bigcirc, 10-6$ dilution. Solid symbols indicate large cells, open symbols indicate small cells. 
Table 2. Functional diversity indices determined in $A$ and $B$ horizon forested and cultivated Guernsey silt loam soil using GN BIOLOG plates inoculated with small cells enriched in dilution culture.

\begin{tabular}{|c|c|c|c|c|}
\hline Sample $^{\mathrm{a}}$ & Sum of Activities & AWCD $^{c}$ & Richness $^{\mathrm{d}}$ & \\
\hline
\end{tabular}

F-A Horizon

$\begin{array}{lllll}\text { SC 10-1 } & 99.3 & 1.04 & 74 & 4.27 \\ \text { SC 10-2 } & 72.1 & 0.76 & 56 & 4.02 \\ \text { SC 10-3 } & 32.1 & 0.34 & 43 & 4.09 \\ \text { SC 10-4 } & 31.3 & 0.33 & 37 & 3.86 \\ \text { SC 10-5 } & 14.0 & 0.15 & 16 & 3.81\end{array}$

F-B Horizon

$\begin{array}{rrrrr}\text { SC 10-1 } & 62.1 & 0.65 & 67 & 4.22 \\ \text { SC 10-3 } & 9.1 & 0.10 & 10 & 3.47\end{array}$

C-A Horizon

SC 10-1

SC 10-2

111.9

1.18

78

4.31

SC 10-3

82.8

0.87

70

4.20

SC 10-4

46.2

0.49

55

4.04

SC 10-5

70.3

0.74

68

4.23

C-B Horizon

62.6

0.66

61

4.17

$\begin{array}{lrrrr}\text { SC 10-1 } & 75.4 & 0.79 & 67 & 4.21 \\ \text { SC 10-2 } & 17.0 & 0.18 & 21 & 4.24 \\ \text { SC 10-3 } & 6.0 & 0.06 & 8 & 3.42 \\ \text { SC 10-4 } & 11.0 & 0.12 & 17 & 3.94 \\ \text { SC 10-5 } & 2.9 & 0.03 & 4 & 2.84\end{array}$

${ }_{\mathrm{a}}^{\mathrm{a}}$, forested site; C, cultivated site; SC, small cells $(<0.45 \mu \mathrm{m})$; LC, large cells $(>0.45 \mu \mathrm{m})$; 10-1 to 10-6, dilution

${ }^{\mathrm{b}}$ Average sum of activities $=$ average sum of absorbance values from triplicate plates

${ }^{\mathrm{C}}$ Average well color development $(\mathrm{AWCD})=$ average sum of activities $/ 95$

${ }^{d}$ Substrate richness $=$ average number of positive wells (absorbance value $>0.25$ )

${ }^{\text {eSubstrate }}$ diversity $=-\Sigma \mathrm{pi}(\mathrm{In} \mathrm{pi})$, where $\mathrm{pi}=$ average absorbance of a single substrate $/$ average sum of activities 

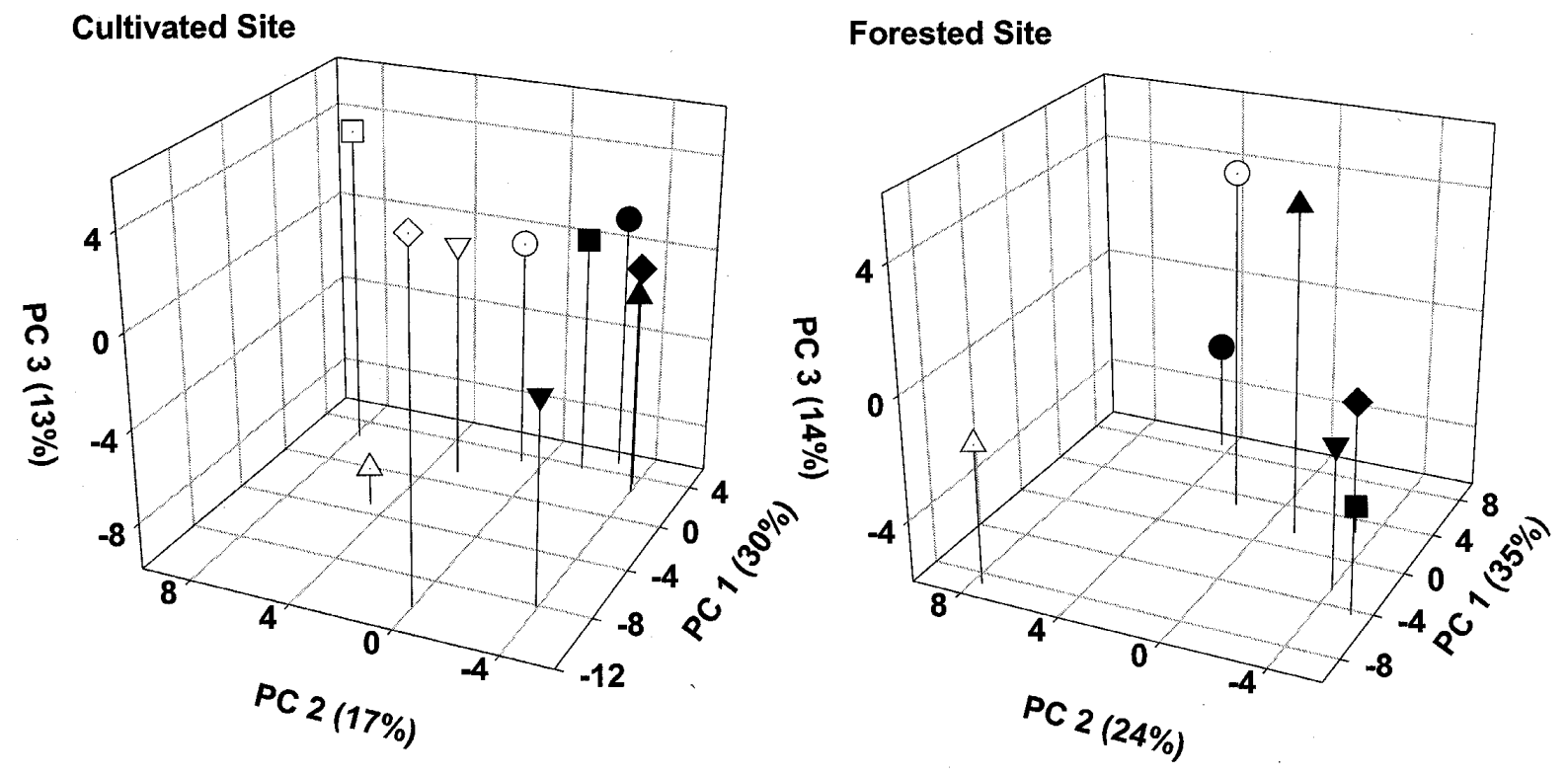

Figure 2. Principle component analyses of small cells extracted from $A$ and $B$ horizons of forested and cultivated Guernsey silt loam soil and enriched in dilution culture. Numbers in parentheses indicate the percent of variation accounted for by each principle component. Symbols are as follows: $O$, 10-1 dilution; $\square$, 10-2 dilution; $\triangle$, 10-3 dilution; $\nabla, 10-4$ dilution; $\diamond, 10-5$ dilution. Solid symbols indicate $A$ horizon samples, open symbols indicate $\mathrm{B}$ horizon samples. 


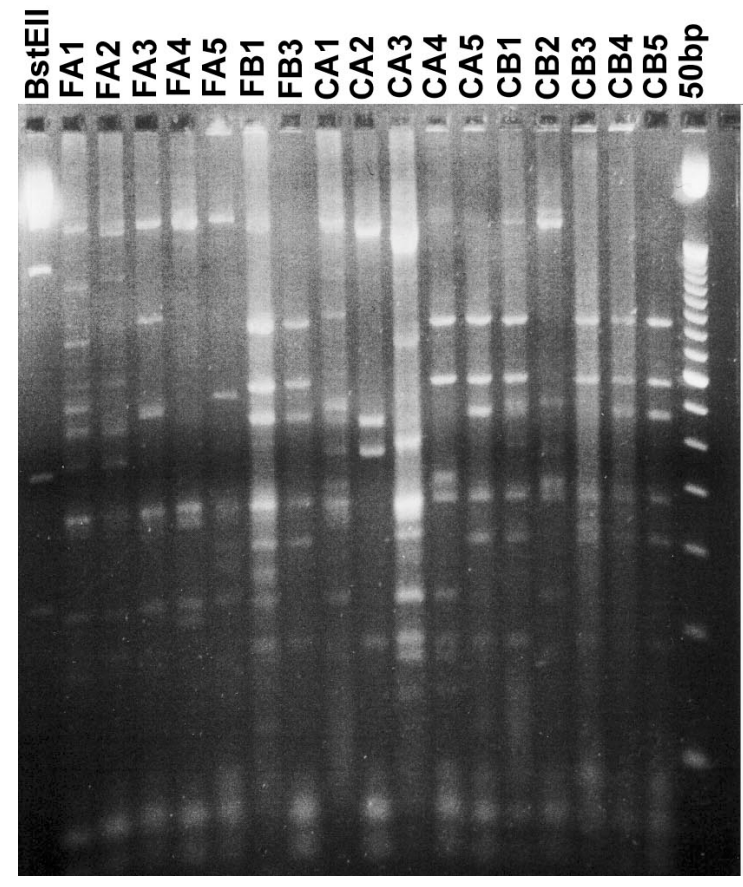

Sau 3Al

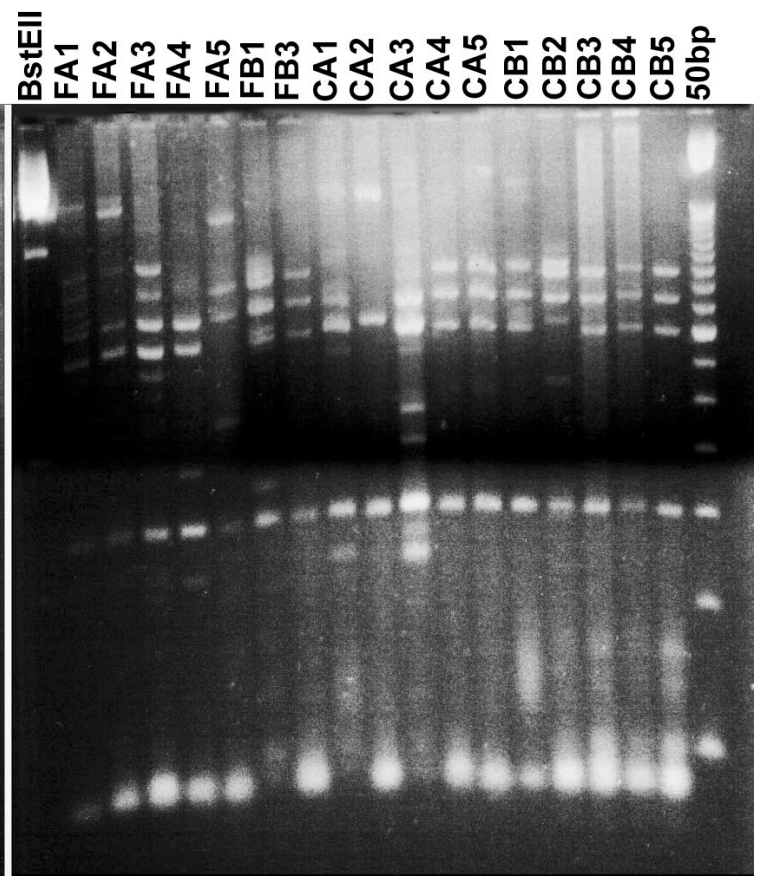

Rsa I

Figure 3. ARDRA analyses of small-celled bacteria extracted from $A$ and $B$ horizons of forested and cultivated Guernsey silt loam soil and enriched in dilution culture. Sau 3AI and Rsa I indicate restriction enzymes used in digestion. Lane markers are as follows: BstEll (digest of bacteriophage lambda) and $50 \mathrm{bp}$ (ladder, GIBCO-BRL), size-markers; F, forested site; C, cultivated site; A, A horizon; B, B horizon; 1 through 5, dilutions. 


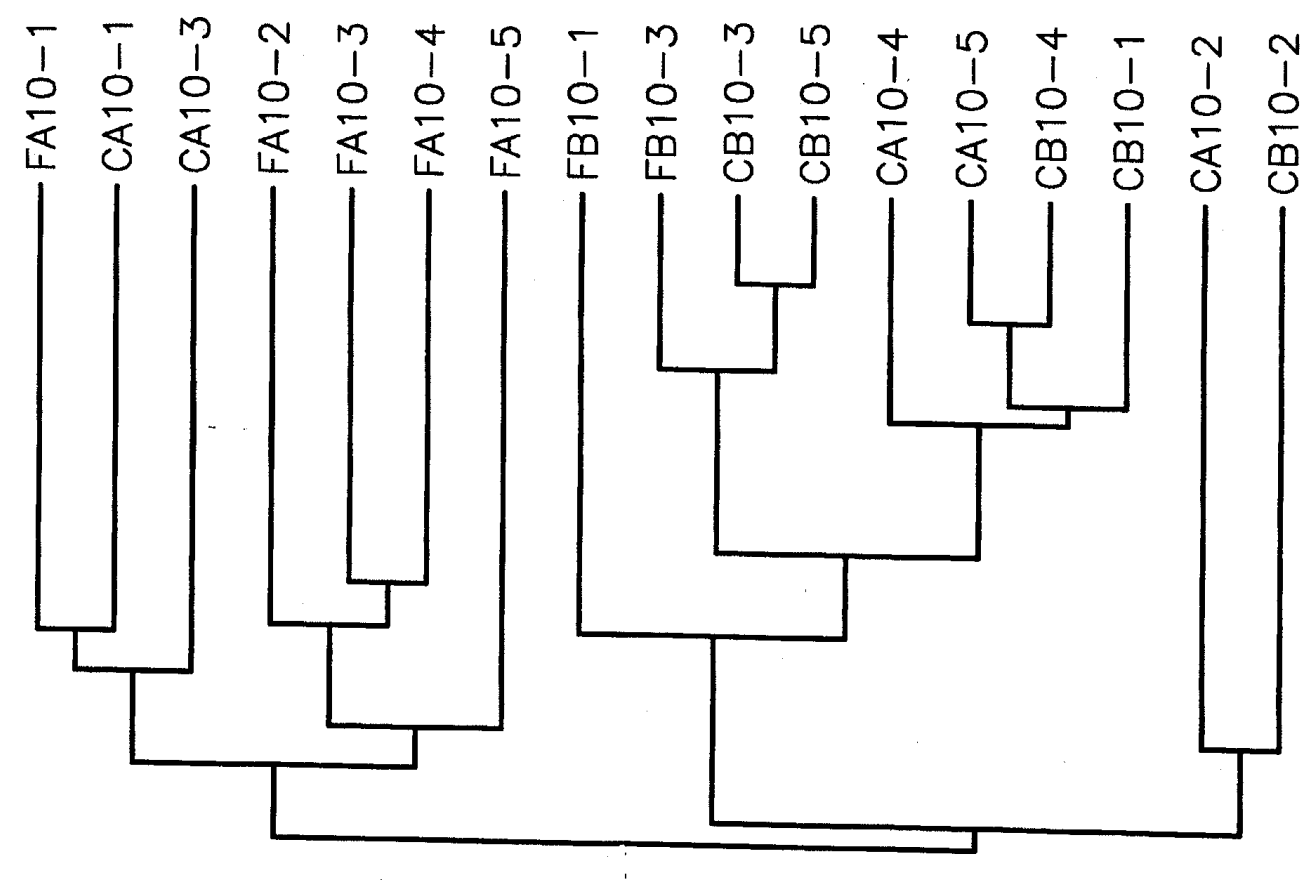

Figure 4. Relationships among small cells from $A$ and $B$ horizons of cultivated and forested Guernsey silt loam soil established with the UPGMA (Unweighted Pair Group Maximum Averages) method, based on a distance matrix generated from RFLPs in 16S rDNA (combined Sau 3Al and Rsa I data). F, forested site; C, cultivated site; A, A horizon; B, B horizon; 10-1 through 10-5, dilutions 


\section{APPENDIX I}

METHODS OF CELL EXTRACTION, ENUMERATION, AND BIOLOG ${ }^{\circledR}$ INOCULATION 
$50 \mathrm{~g}$ soil

$200 \mathrm{ml}$ Winogradsky's Salt Solution (WSS)

1 drop Tween 80
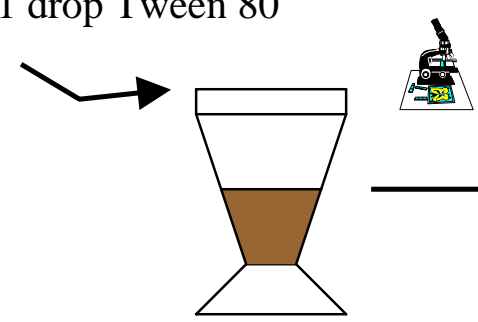

Blend for three 1-minute intervals with intermittent cooling on ice

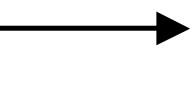

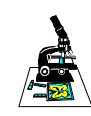

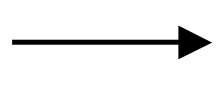

Centrifuge at $2500 \mathrm{rpm}$, $15 \mathrm{~min}$ to remove soil particles (x2)

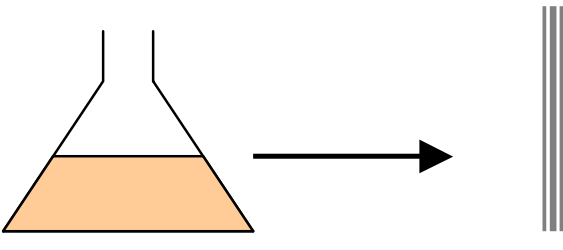

Pass through a $0.45 \mu \mathrm{m}$ Millipore ${ }^{\circledR}$ filter $500 \mathrm{ml} \mathrm{WSS}$

\section{迹}

Filtrate contains cells $<0.45 \mu \mathrm{m}(\mathrm{SC})$
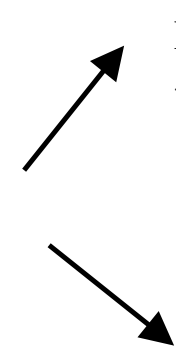

Wash filter surface to collect cells $>0.45 \mu \mathrm{m}$ (LC)

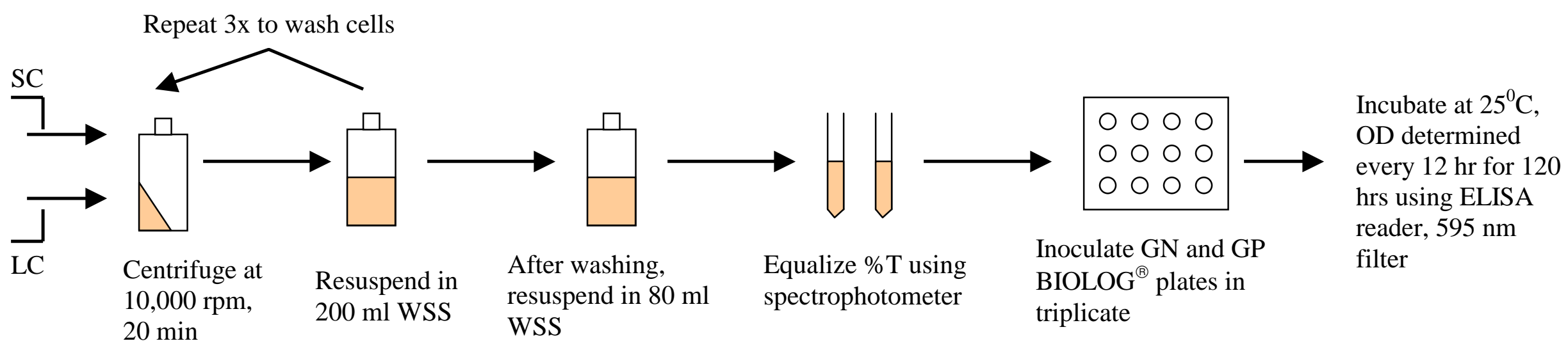

Figure 1. Methods of cell extraction, enumeration, and BIOLOG ${ }^{\circledR}$ inoculation. performed using FITC (fluorescein isothiocyanate) staining. 


\section{APPENDIX II}

ADDITIONAL DATA NOT PRESENTED IN CHAPTER 2 


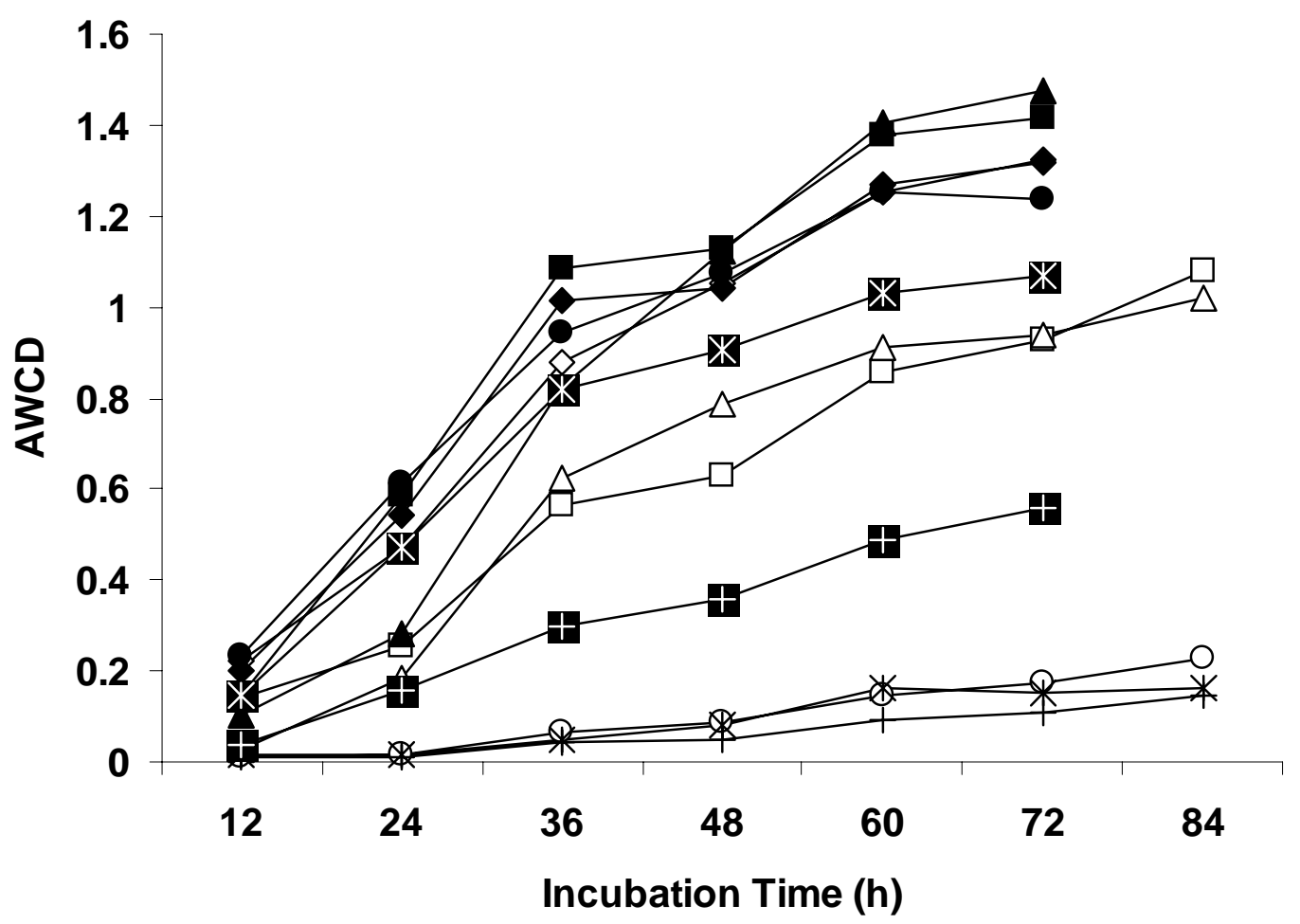

Figure 1. Average well color development (AWCD) from GN BIOLOG plates with time for large (LC) and small (SC)-celled bacteria extracted from A horizon forested Guernsey silt loam soil and enriched in dilution culture. Symbols are as follows: $\diamond$, 10-1 dilution; $\square$, 10-2 dilution; $\triangle$, 10-3 dilution; $O$, 10-4 dilution; $*, 10-5$ dilution; ,$+ 10-6$ dilution. Solid symbols indicate LC, open symbols indicate SC. 


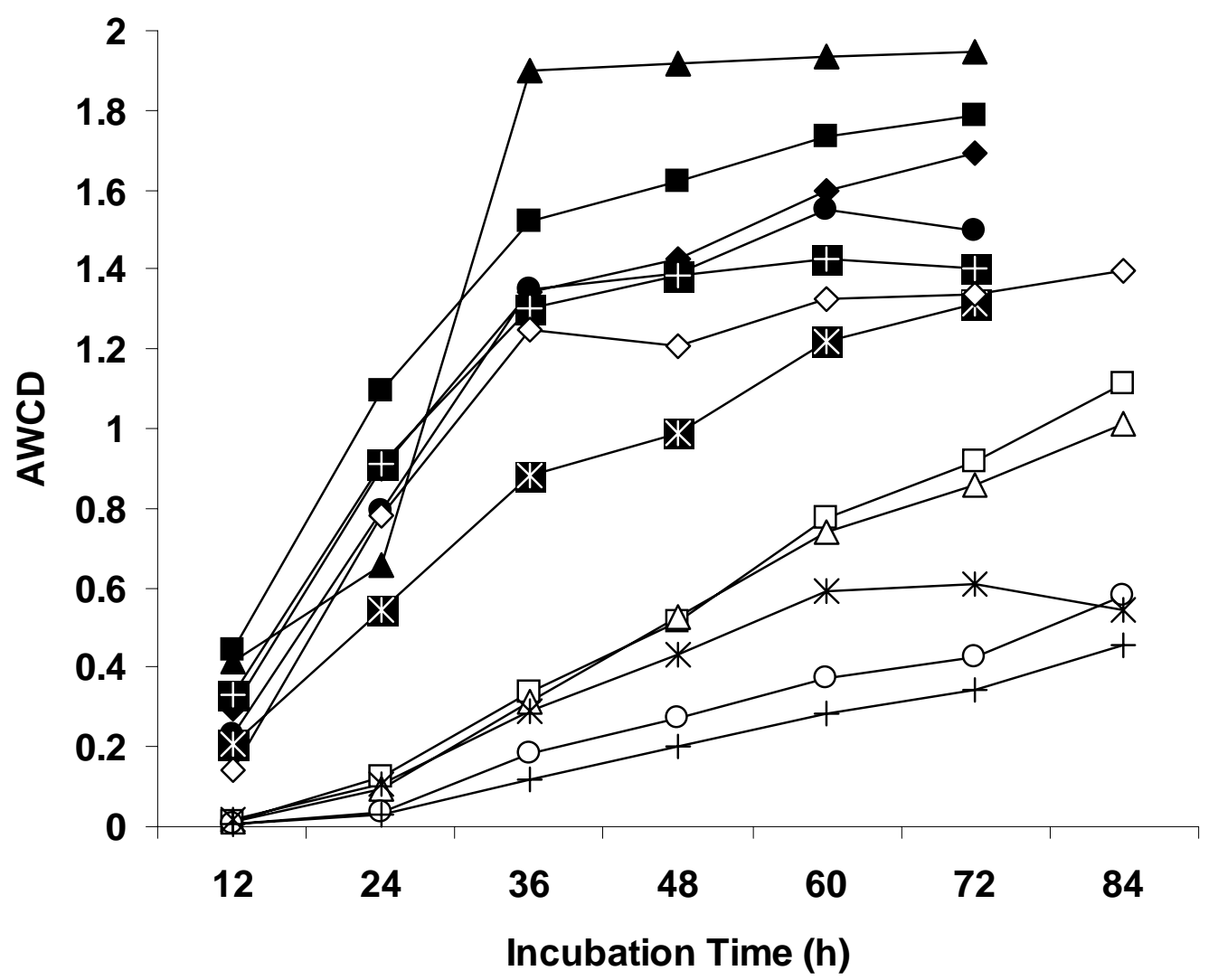

Figure 2. Average well color development (AWCD) from GN BIOLOG plates with time for large (LC) and small (SC)-celled bacteria extracted from A horizon cultivated Guernsey silt loam soil and enriched in dilution culture. Symbols are as follows: $\diamond$, 10-1 dilution; $\square$, 10-2 dilution; $\triangle$, 10-3 dilution; 0 , 10-4 dilution; $*$, 10-5 dilution; ,$+ 10-6$ dilution. Solid symbols indicate LC, open symbols indicate SC. 


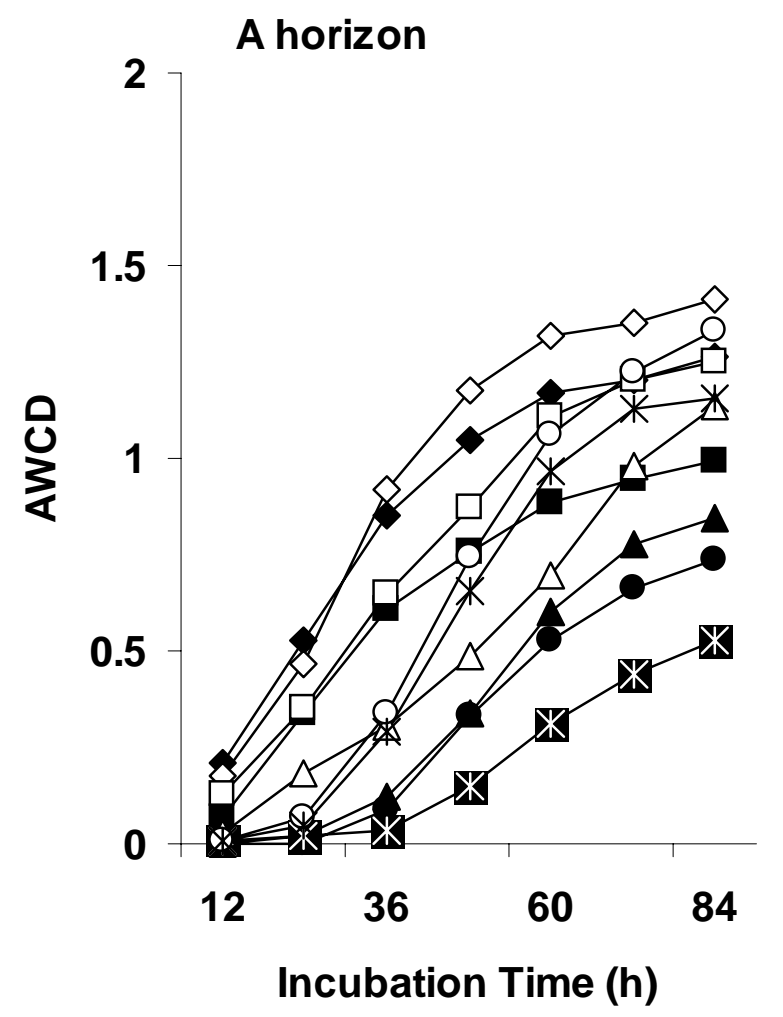

\section{B horizon}

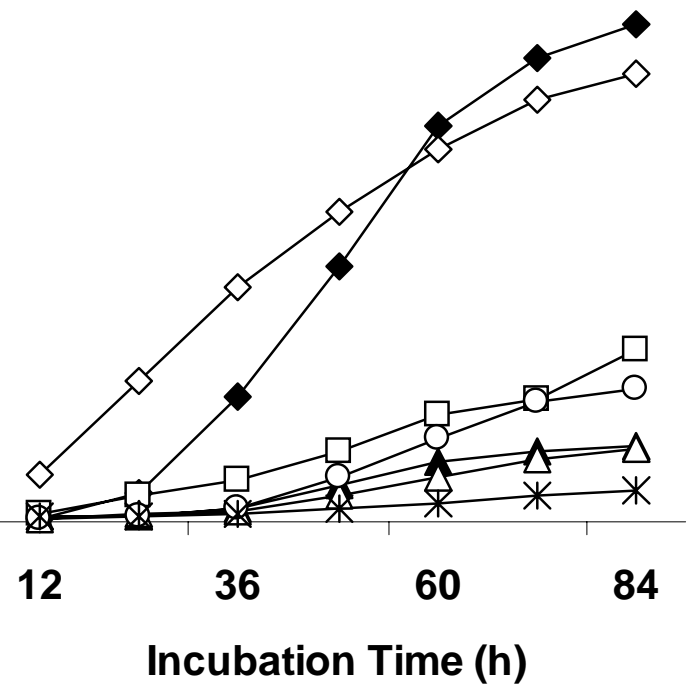

Figure 3. Average well color development (AWCD) from GN BIOLOG plates with time for small-celled bacteria extracted from A horizon cultivated and forested Guernsey silt loam soil and enriched in dilution culture. Symbols are as follows:

$\diamond$, 10-1 dilution; $\square, 10-2$ dilution; $\triangle, 10-3$ dilution; $O$, 10-4 dilution; $*, 10-5$ dilution. Solid symbols indicate forested site enrichments, open symbols indicate cultivated site enrichments. 

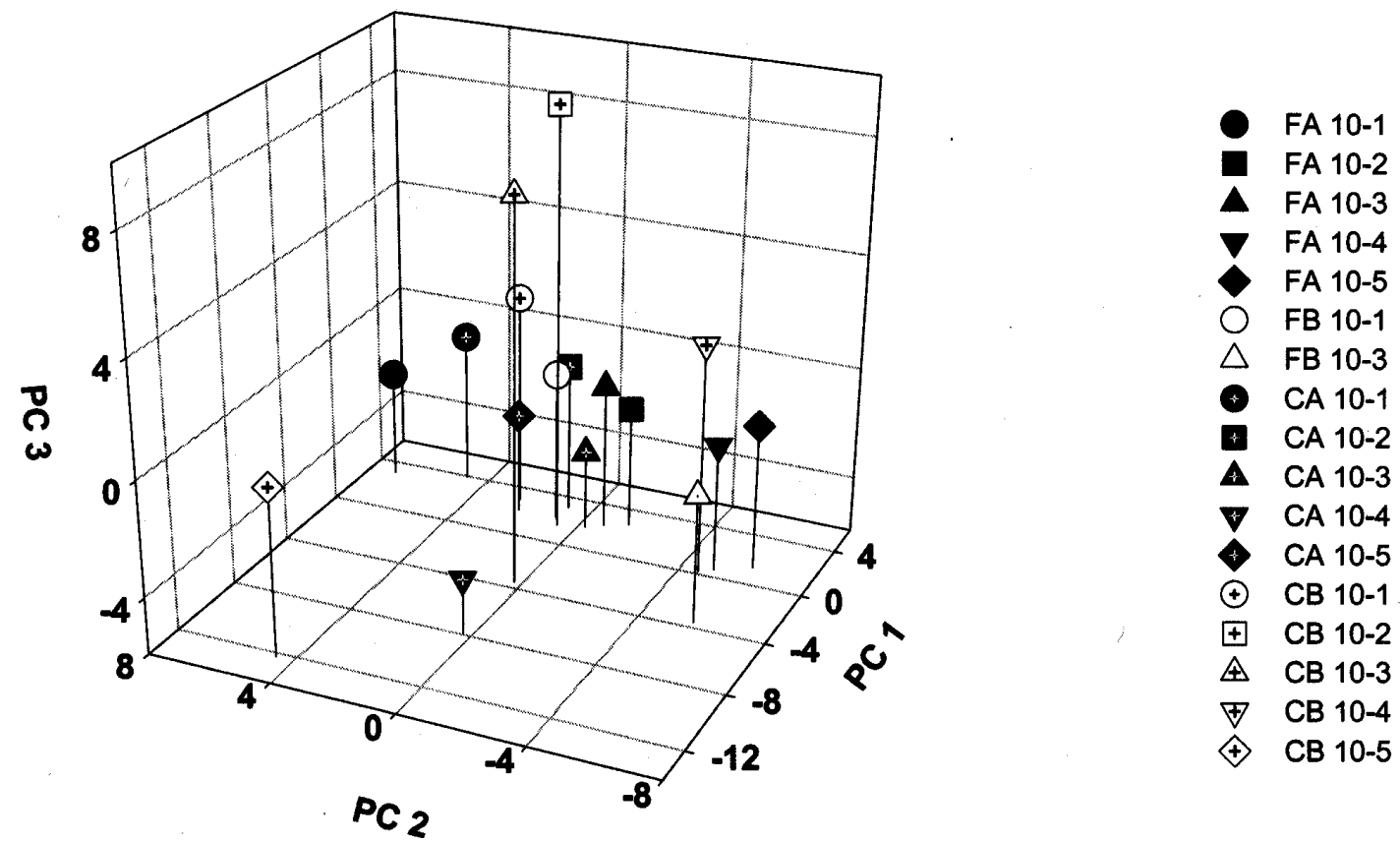

Figure 4. Principle component analysis based on adjusted AWCD (average absorbance value for each substrate divided by AWCD) from GN BIOLOG plates inoculated with small-celled bacteria extracted from $A$ and $B$ horizons of forested and cultivated Guernsey silt loam soil. Abbreviations are as follows: F, forested; $C$, cultivated; $A, A$ horizon; B, B horizon; 10-1 through 10-5, dilutions. 

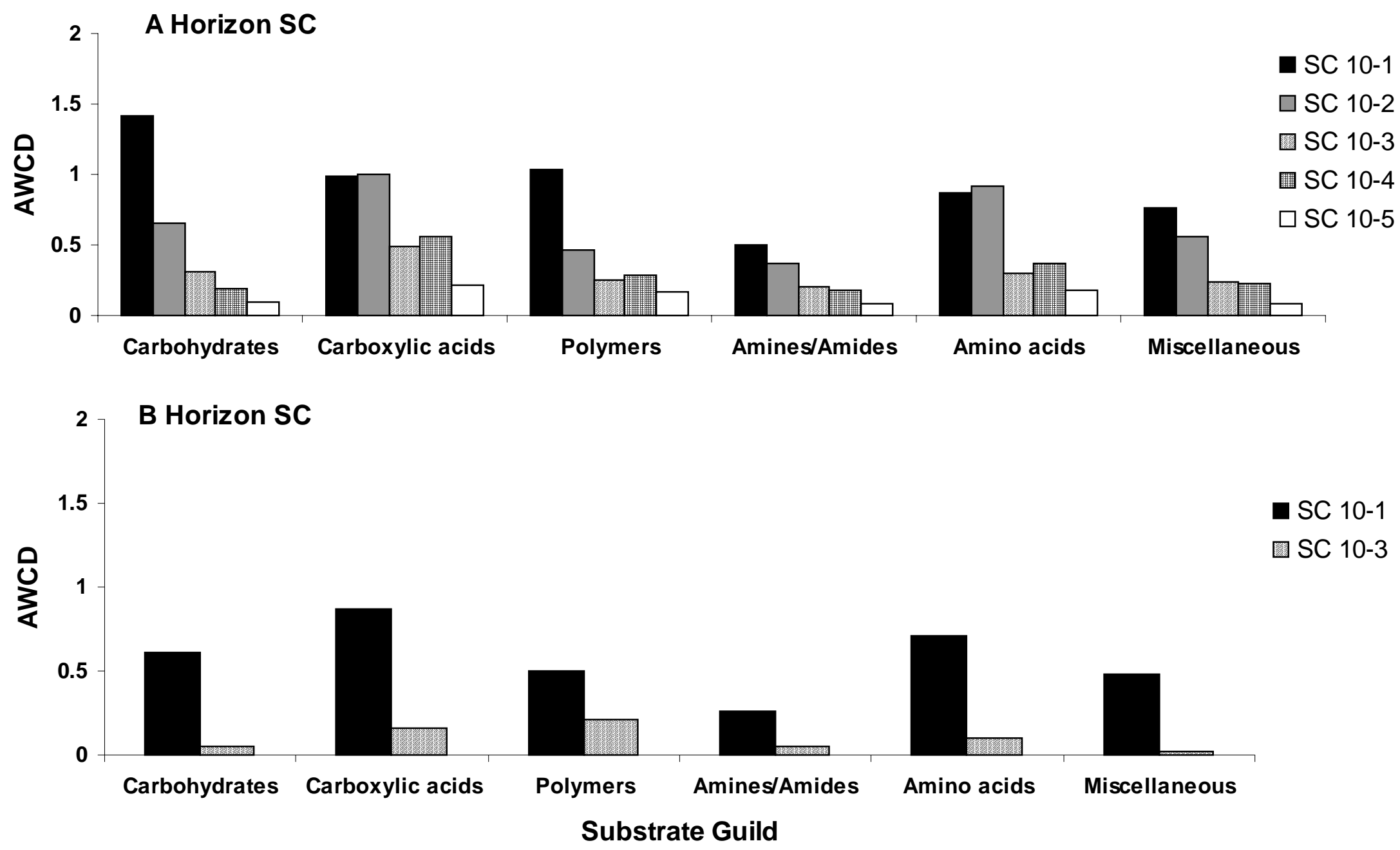

Figure 5. Average well color development (AWCD) per substrate guild from GN BIOLOG plates inoculated with smallcelled (SC) bacteria extracted from A and B horizons of forested Guernsey silt loam soil and enriched in dilution culture. 

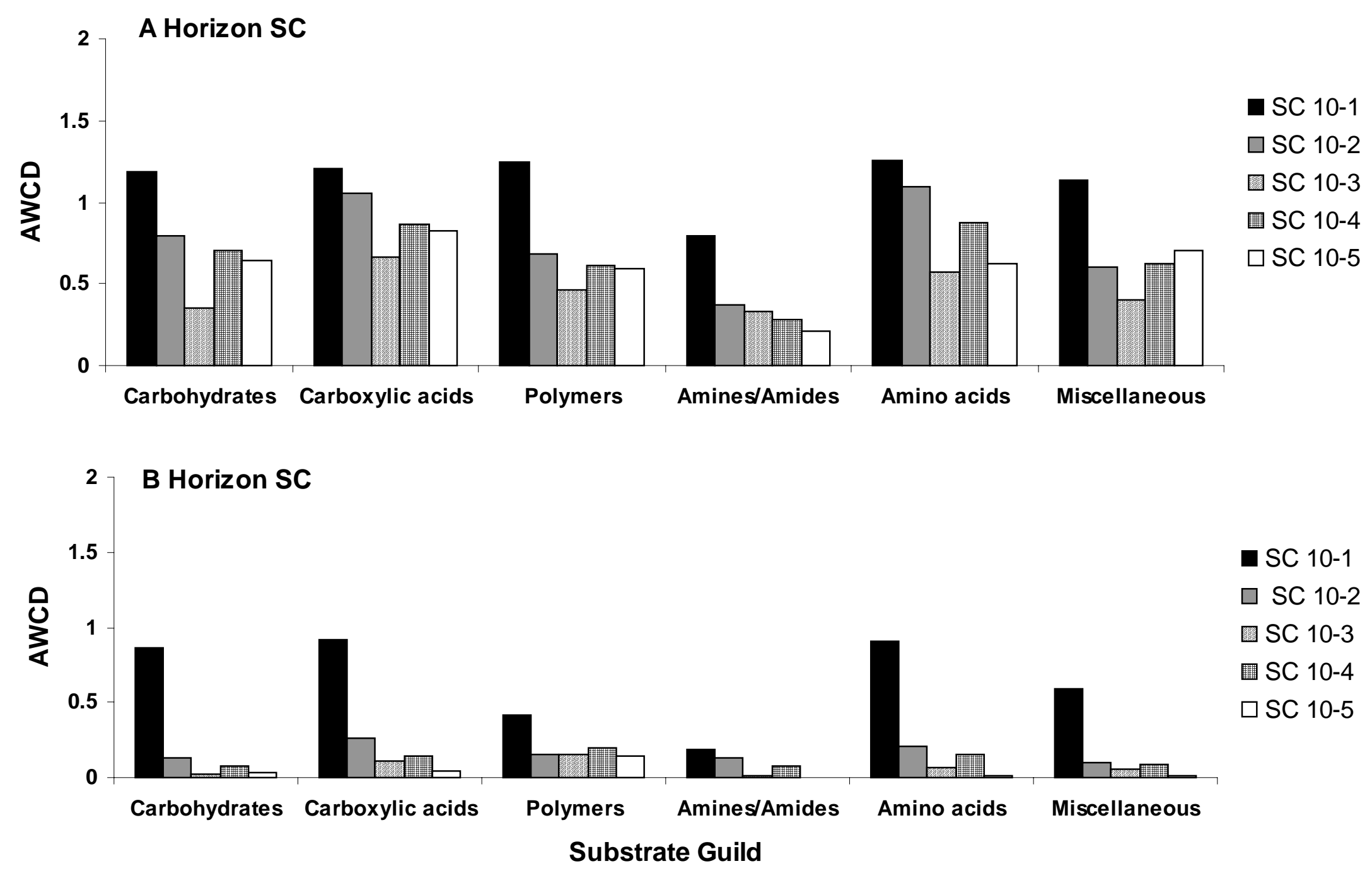

Figure 6. Average well color development (AWCD) per substrate guild from GN BIOLOG plates inoculated with small-celled (SC) bacteria extracted from A and B horizons of cultivated Guernsey silt loam soil and enriched in dilution culture. 
Table 1. Estimated width and length of small cells extracted from $A$ and $B$ horizons of forested and cultivated Guernsey silt-loam soil following enrichment in dilution culture.

\begin{tabular}{rrc}
\hline \multicolumn{1}{c}{ Sample $^{*}$} & Estimated Width $(\mu \mathrm{m})$ & Estimated Length $(\mu \mathrm{m})$ \\
\hline \hline Forested Site, A Horizon & & \\
SC 10-1 & $<0.5$ & $>0.5$ \\
SC 10-2 & $<0.5$ & $>0.5$ \\
SC 10-3 & $<0.5$ & $>0.5$ \\
SC 10-4 & $<0.5$ & $>0.5$ \\
SC 10-5 & $<0.5$ & $>0.5$ \\
& & \\
Forested Site, B horizon & $<0.5$ & $>0.5$ \\
SC 10-1 & $<0.5$ & $>0.5$ \\
SC 10-3 & & \\
& & \\
Cultivated Site, A horizon & $<0.5$ & $>0.5$ \\
SC 10-1 & $<0.5$ & $>0.5$ \\
SC 10-2 & $<0.5$ & $>0.5$ \\
SC 10-3 & $<0.5$ & $>0.5$ \\
SC 10-4 & $<0.5$ & $>0.5$ \\
SC 10-5 & & \\
& & $>0.5$ \\
Cultivated Site, B horizon & $<0.5$ & $>0.5$ \\
SC 10-1 & $<0.5$ & $\sim 1$ \\
SC 10-2 & $<0.5$ & $>0.5$ \\
SC 10-3 & $<0.5$ & \\
SC 10-4 & SC 10-5 & \\
\hline \hline
\end{tabular}

${ }^{*} \mathrm{SC}$, small cells $(<0.45 \mu \mathrm{m}$ before enrichment); $10-1$ through $10-5$, dilution 
Table 2. Estimated width and length of small (SC) and large (LC) cells extracted from $A$ and $B$ horizons of forested and cultivated Guernsey silt-loam soil without enrichment.

\begin{tabular}{lcc}
\hline \multicolumn{1}{c}{ Sample } & Estimated Width $(\mu \mathrm{m})$ & Estimated Length $(\mu \mathrm{m})$ \\
\hline \hline Forested-A LC & $>0.5$ & $>1$ \\
Forested-B LC & $>0.5$ & $>1$ \\
Cultivated-A LC & $>0.5$ & $\sim 1$ \\
Cultivated-B LC & $>0.5$ & $>0.5$ \\
& & \\
Forested-A SC & $<0.5$ & $<0.5$ \\
Forested-B SC & $<0.5$ & $<0.5$ \\
Cultivated-A SC & $<0.5$ & $<0.5$ \\
Cultivated-B SC & $<0.5$ & $<0.5$ \\
\hline \hline
\end{tabular}


Table 3. Average richness per substrate guild determined in GN BIOLOG plates inoculated with small-celled bacteria $(<0.45 \mu \mathrm{m})$ extracted from A and B horizons of forested and cultivated Guernsey silt loam soil and enriched in dilution culture.

\begin{tabular}{|c|c|c|c|c|c|c|}
\hline Sample $^{*}$ & Carbohydrates & Carboxylic acids & Polymers & Amines/Amides & Amino Acids & Miscellaneous \\
\hline F-A Horizon & 25 & 18 & 4 & 4 & 16 & 7 \\
\hline SC $10-1$ & 15 & 17 & 2 & 2 & 14 & 5 \\
\hline SC $10-2$ & 11 & 14 & 2 & 3 & 10 & 3 \\
\hline SC $10-3$ & 9 & 12 & 2 & 2 & 9 & 4 \\
\hline SC $10-4$ & 4 & 5 & 2 & 1 & 4 & 1 \\
\hline \multicolumn{7}{|l|}{$\begin{array}{l}\text { SC 10-5 } \\
\text { F-B Horizon }\end{array}$} \\
\hline SC $10-1$ & 21 & 19 & 3 & 3 & 14 & 7 \\
\hline SC 10-3 & 2 & 4 & 1 & 0 & 2 & 0 \\
\hline \multicolumn{7}{|l|}{ C-A Horizon } \\
\hline SC 10-1 & 22 & 22 & 5 & 5 & 15 & 9 \\
\hline SC $10-2$ & 21 & 21 & 3 & 3 & 16 & 6 \\
\hline SC $10-3$ & 16 & 16 & 3 & 2 & 12 & 6 \\
\hline SC $10-4$ & 20 & 19 & 3 & 2 & 16 & 8 \\
\hline SC $10-5$ & 25 & 18 & 2 & 2 & 15 & 6 \\
\hline \multicolumn{7}{|l|}{ C-B Horizon } \\
\hline SC 10-1 & 25 & 18 & 2 & 2 & 15 & 6 \\
\hline SC $10-2$ & 4 & 8 & 1 & 1 & 5 & 2 \\
\hline SC $10-3$ & 0 & 3 & 1 & 0 & 2 & 1 \\
\hline SC $10-4$ & 2 & 5 & 2 & 1 & 5 & 2 \\
\hline SC $10-5$ & 1 & 1 & 1 & 0 & 0 & 0 \\
\hline
\end{tabular}

${ }^{*}$ F, forested site; C, cultivated site; A, A horizon; B, B horizon; SC, small cells $(<0.45 \mu \mathrm{m})$; 10-1 through 10-5, dilutions. 
Table 4. Specific substrates utilized by selected enrichment cultures of small-celled bacteria extracted from forested A horizon Guernsey silt loam soil.

\begin{tabular}{|c|c|c|c|c|c|c|}
\hline Sample $^{a}$ & Carbohydrates & Carboxylic acids & Polymers & Amines/Amides & Amino Acids & Miscellaneous \\
\hline SC 10-6 & $\begin{array}{l}\text { D-psicose } \\
\text { D-mannose }\end{array}$ & $\begin{array}{l}* \beta \text {-hydroxybutyric acid } \\
\text { succinic acid }\end{array}$ & $\begin{array}{l}{ }^{*} \text { tween } 40 \\
\text { *tween } 80\end{array}$ & & $\begin{array}{l}{ }^{*} \text { L-glutamic acid } \\
\text { L-proline }\end{array}$ & \\
\hline SC 10-5 & $\begin{array}{l}\text { D-melibiose } \\
{ }^{*} \beta \text {-methyl-D-glucoside } \\
\text { D-trehalose } \\
\text { D-galactose } \\
{ }^{*} \text { D-mannitol } \\
\text { D-psicose } \\
\text { D-sorbitol } \\
\text { D-raffinose }\end{array}$ & $\begin{array}{l}\text { citric acid } \\
\text { D-galacturonic acid } \\
\beta \text {-hydroxybutyric acid } \\
\text { succinic acid } \\
\text { D-glucuronic acid } \\
\text { p-hydroxy phenylacetic acid } \\
\text { quinic acid }\end{array}$ & $\begin{array}{l}\text { dextrin } \\
\text { glycogen } \\
\text { *tween } 40\end{array}$ & & $\begin{array}{l}\text { L-glutamic acid } \\
\text { L-asparagine }\end{array}$ & \\
\hline SC 10-4 & $\begin{array}{l}\text { D-fructose } \\
D \text {-psicose } \\
\alpha \text {-D-lactose }\end{array}$ & $\begin{array}{l}\text { propionic acid } \\
\beta \text {-hydroxybutyric acid } \\
\text { citric acid } \\
\alpha \text {-keto valeric acid } \\
\text { D,L-lactic acid } \\
\text { D-saccharic acid }\end{array}$ & $\begin{array}{l}\text { dextrin } \\
\text { *tween } 40\end{array}$ & & & $\begin{array}{l}\text { urocanic acid } \\
\text { glucose-1-phosphate }\end{array}$ \\
\hline
\end{tabular}

${ }^{*}$ indicates that 2 or more of the triplicate plates had an OD $>0.25$ for these substrates

${ }^{a}$ SC, small cells $(<0.45 \mu \mathrm{m}) ; 10-4$ through $10-6$, dilutions 
Table 5. Specific substrates utilized by selected enrichment cultures of small-celled bacteria extracted from cultivated A horizon Guernsey silt loam soil.

\begin{tabular}{|c|c|c|c|c|c|c|}
\hline Sample $^{\mathrm{a}}$ & Carbohydrates & Carboxylic acids & Polymers & Amines/Amides & Amino Acids & Miscellaneous \\
\hline SC 10-6 & $\begin{array}{l}\text { L-arabinose } \\
{ }^{*} \text { D-galactose } \\
\text { gentiobiose } \\
\text { mono-methyl } \\
\text { succinate } \\
\text { methyl pyruvate } \\
\text { sucrose } \\
\text { D-raffinose } \\
\beta \text {-methyl-D-glucoside } \\
\text { D-melibiose } \\
\text { cellobiose }\end{array}$ & $\begin{array}{l}\text { *acetic acid } \\
\text { citric acid } \\
{ }^{*} \beta \text {-hydroxybutyric acid } \\
\gamma \text {-hydroxybutyric acid } \\
\text { L-hydroxyphenylacetic acid } \\
{ }^{*} D, L \text {-lactic acid } \\
\text { propionic acid } \\
\text { succinic acid }\end{array}$ & $\begin{array}{l}\text { "dextrin } \\
\text { *tween } 40 \\
\text { *tween } 80\end{array}$ & $\begin{array}{l}\text { succinamic acid } \\
\text { *glucuronamide } \\
\text { *alaninamide } \\
\text { putrescine }\end{array}$ & $\begin{array}{l}\text { D-alanine } \\
{ }^{*} \text { L-asparagine } \\
{ }^{*} \text { L-aspartic acid } \\
{ }^{*} \text { L-glutamic acid } \\
\text { glycyl-L-glutamic acid } \\
{ }^{*} \text { L-proline } \\
\text { L-serine } \\
\gamma \text {-amino-butyric acid }\end{array}$ & $\begin{array}{l}\text { inosine } \\
\text { thymidine } \\
\text { *glucose-1-phosphate } \\
{ }^{*} \text { glucose-6-phosphate }\end{array}$ \\
\hline SC 10-5 & & & & succinamic acid & & $\begin{array}{l}\text { *bromo succinic acid } \\
\text { *inosine } \\
\text { uridine } \\
{ }^{*} \text { glycerol }\end{array}$ \\
\hline SC 10-4 & $\begin{array}{l}{ }^{*} \text { citric acid } \\
\text { D-galactonic acid lactone } \\
D \text {-galacturonic acid } \\
{ }^{*} \beta \text {-hydroxybutyric acid } \\
\gamma \text {-hydroxybutyric acid } \\
\text { itaconic acid } \\
\alpha \text {-keto-glutaric acid } \\
\alpha \text {-keto-valeric acid } \\
\text { malonic acid } \\
\text { propionic acid } \\
\text { quinic acid } \\
\text { D-saccharic acid } \\
\text { succinic acid }\end{array}$ & $\begin{array}{l}\alpha \text {-cyclodextrin } \\
\text { glycogen } \\
{ }^{*} \text { tween } 40\end{array}$ & $\begin{array}{l}\text { glucuronamide } \\
\text { putrescine } \\
\text { 2-amino ethanol }\end{array}$ & $\begin{array}{l}{ }^{*} \text { L-aspartic acid } \\
{ }^{*} \text { L-glutamic acid } \\
\text { *glycyl-L-glutamic acid } \\
\text { L-histidine } \\
\text { L-leucine } \\
\text { L-ornithine } \\
\text { L-phenylalanine } \\
\text { L-serine } \\
\gamma \text {-amino butyric acid }\end{array}$ & & $\begin{array}{l}\text { bromo succinic acid } \\
\text { urocanic acid } \\
\text { 2,3-butanediol } \\
\text { D,L- } \alpha \text {-glycerol phosphate } \\
\text { "glucose-1-phosphate } \\
\text { glucose-6-phosphate }\end{array}$ \\
\hline
\end{tabular}

